\title{
Tree species identity alters decomposition of understory litter and associated microbial communities : a case study
}

\section{Angst, Sarka}

2019-07

Angst , S , Harantova , L , Baldrian , P , Angst , G , Cajthaml , T , Strakova , P , Blahut , J , Vesela, H \& Frouz , J 2019 , ' Tree species identity alters decomposition of understory litter and associated microbial communities : a case study ' , Biology and Fertility of Soils , vol. 55 , no. 5 , pp. 525-538 . https://doi.org/10.1007/s00374-019-01360-z

http://hdl.handle.net/10138/308751

https://doi.org/10.1007/s00374-019-01360-z

Downloaded from Helda, University of Helsinki institutional repository.

This is an electronic reprint of the original article.

This reprint may differ from the original in pagination and typographic detail.

Please cite the original version. 
Tree species identity alters decomposition of understory litter and associated microbial communities: a case study

$\breve{S}$ árka Angst $^{\mathrm{a}, \mathrm{b}}$, Lenka Harantovác ${ }^{\mathrm{c}}$, Petr Baldrian ${ }^{\mathrm{c}}$, Gerrit Angst ${ }^{\mathrm{a}}$, Tomáš Cajthaml ${ }^{\mathrm{c}, \mathrm{d}}$, Petra Straková, ${ }^{\mathrm{e}, \mathrm{f}}$, Jan Blahut ${ }^{\mathrm{g}}$, Hana Veselád ${ }^{\mathrm{d}}$ Jan Frouz $^{\mathrm{a}, \mathrm{d}}$

${ }^{a}$ Biology Centre of the Czech Academy of Sciences, v. v. i., SoWa Research Infrastructure \& Institute of Soil Biology, Na Sádkách 7, CZ 37005 České Budějovice, Czech Republic

${ }^{\mathrm{b}}$ Department of Ecosystem Biology, Faculty of Science, University of South Bohemia, Branišovská 31, CZ 37005 České Budějovice, Czech Republic

${ }^{\mathrm{c}}$ Institute of Microbiology of the Czech Academy of Sciences, v. v. i., Vídeňská 1083, CZ 14220 Praha, Czech Republic

${ }^{\mathrm{d}}$ Institute for Environmental Studies, Faculty of Science, Charles University in Prague, Benátská 2, CZ 12800, Praha 2, Czech Republic

${ }^{\mathrm{e}}$ Department of Forest Sciences, Peatland Ecology Group, Latokartanonkaari 7, FI-00014 University of Helsinki, Helsinki, Finland

${ }^{\mathrm{f}}$ Natural Resources Institute Finland (Luke), Latokartanonkaari 9, FI-00790 Helsinki, Finland

${ }^{\mathrm{g}}$ Department of Inorganic Chemistry, Faculty of Science, Charles University in Prague, Hlavova 2030/8, CZ 12800, Praha 2, Czech Republic

Corresponding author: Šárka Angst, sarka.angst@gmail.com, TEL: +420 387775782

ORCID: Šárka Angst 0000-0002-5244-328X; Petr Baldrian 0000-0002-8983-2721; Gerrit Angst 0000-0003-4421-5444; Tomáš Cajthaml 0000-0002-3393-1333; Jan Blahut 0000-00017752-8370; Hana Veselá 0000-0002-7061-7263; Jan Frouz 0000-0002-0908-8606 


\section{Acknowledgments}

The study was supported by the European Regional Development Fund-Project „Research of key soil-water ecosystem interactions at the SoWa Research Infrastructure“ [EF16_013/0001782 - SoWa Ecosystems Research] and by the Czech Science Foundation [18-24138S]. The study was realized within the SoWa Research Infrastructure funded by the Ministry of Education, Youth, and Sport of the Czech Republic [LM2015075], program "Projects of Large Infrastructure for Research, Development, and Innovations". 


\begin{abstract}
Investigations on how tree species modify decomposition of understory litter have rarely been conducted, although potentially having impacts on soil carbon stocks and stability. The aim of our study was to disentangle the effects different tree species (alder, spruce, oak, and willow) exert on litter decomposition by comparing decomposition patterns and microbial measures (phospholipid fatty acids and microbial DNA) of both tree and understory (Calamagrostis epigejos) litter exposed at the respective tree species stands of a common garden experiment. An initially uniform mass loss of understory litter exposed at the stands suggests that inherent litter quality (assessed by $\mathrm{C}: \mathrm{N}$ ratios and lignin content) was the major driver in early decomposition. However, in later stages of our experiment, decomposition of understory litter began to differ among the stands, suggesting a delayed tree species effect. Here, differences in microbial community composition caused by tree species identity (e.g., through varying $\mathrm{N}$ supply or phenolics leached from low quality litter) were likely the major determinants affecting the decomposition of understory litter. However, in these advanced decomposition stages, tree species identity only partly altered microbial communities associated with understory litter. These results indicate that the development of microbial communities on understory litter (and its decay) is likely a combined result of inherent chemical composition and tree species identity.
\end{abstract}

Keywords: Common garden experiment; Litter chemistry; PLFA; DNA; Bacteria; Fungi 


\section{Introduction}

In forest ecosystems, trees are known to profoundly affect soil development, including the thickness of organic and organo-mineral layers (Frouz et al. 2013), pH (Chodak and Niklińska 2010), carbon (C) and nitrogen (N) dynamics (Gartner and Cardon 2004; Hobbie et al. 2007; Cepáková et al. 2016; Angst et al. 2019), or soil microbial necro- and biomass (Bauhus et al. 1998; Angst et al. 2018). Under similar environmental conditions, such as climate, topography, or soil mineralogy, decomposition and soil development are mainly a function of litter quality (Cotrufo et al. 2009; Laganière et al. 2010a; Urbanová et al. 2014). For various tree species, leaf litter decomposition has been addressed extensively (e.g. Melillo et al. 1982; Cotrufo et al. 2009; Wickings et al. 2012; Cepáková and Frouz 2015), mostly focusing on the direct relationships between initial litter quality and decomposition. Litter decomposition can be accelerated or decelerated by varying nutrient availability, occurrence of inhibitors (e.g. phenolics), or composition and activity of decomposer communities (Hoorens et al. 2003; Gartner and Cardon 2004; Šnajdr et al. 2013), specifically when litters of different quality cooccur in the forest floor (Hättenschwiler 2005). The influence of a combination of different tree species' litter on decomposition, though, has rarely been investigated (Zhao et al. 2013; Qiao et al. 2014). This is particularly true for the decomposition of understory litter, which commonly occurs in many forest ecosystems, can largely contribute to overall litter fall (Mudrák et al. 2010), and notably influences soil C dynamics. Gaining a deeper understanding of how litters of different tree species interact with their understory litter, potentially altering decomposition processes, may thus be crucial for the build-up of soil organic matter (SOM) and, thus, ecosystem management.

To unveil potential effects of the co-occurrence of litter from different plant species on decomposition, we investigated the decomposition of Calamagrostis epigejos in a common garden planted with different tree species (alder, spruce, oak, and willow). Calamagrostis is 
one of the most widespread grasses across Europe (Rebele and Lehmann 2001), suppresses other plant species and successfully colonizes disturbed landscapes (Mudrák et al. 2010), especially in late successional stages (Prach et al. 2001; Frouz et al. 2008). Investigating its decomposition in relation to dominant tree species is thus relevant to $\mathrm{C}$ dynamics in large areas recovering from disturbance, such as post-mining sites or abandoned fields.

Our common garden approach aims to disentangle whether decomposition of understory litter is independent of site-specific conditions developed under the influence of the different tree species, likely leading to similar litter decomposition under all tree species, or whether it is driven by the specific environments different tree stands create, likely causing Calamagrostis litter to depart from uniform decomposition patterns.

Trees affect their environment in various ways. Leachates from the litter of different tree species substantially vary in quality. For example, dissolved organic matter (DOM) from spruce litter has high concentrations of phenolics (low-quality litter; Kiikkilä et al. 2011), while DOM from alder litter is rich in N (high-quality litter; Cepáková et al. 2016); for these reasons, the external supply of potential inhibitors (phenolics) or accelerators of decomposition (such as $\mathrm{N}$ ) may affect the decomposition of understory litter (Laganière et al. 2010b; Shihan et al. 2017). We thus hypothesized that (1) Calamagrostis decomposition will be faster at stands planted with tree species bearing high-quality litter as compared to stands planted with tree species bearing low-quality litter. Moreover, as trees determine a variety of soil characteristics (e.g. Reich et al. 2005; Hobbie et al. 2006; 2007; Frouz et al. 2013) and deliver organic matter $(\mathrm{OM})$ to the soil, they should predominantly drive the development of the soil microbial community because the latter adapts to the chemistry of its substrate (Wallenstein et al. 2013; Urbanová et al. 2015). We thus hypothesized that (2) bacterial and fungal communities associated with the understory litter will not only be influenced by understory chemistry but also by the tissue chemistry of the prevailing tree species (e.g. fungi will dominate at spruce stands, while bacteria will dominate at alder stands). 


\section{Material and methods}

Study area, study sites, and sampling

The field decomposition experiment was performed on a spoil heap in the Sokolov browncoal mining district $\left(50^{\circ} 14^{\prime} 04^{\prime \prime} \mathrm{N}, 12^{\circ} 41^{\prime} 04^{\prime \prime} \mathrm{E}\right.$, Czech Republic, 450 - $520 \mathrm{~m}$ a.s.l.). The spoil heap was formed during the last 50 years by the piling of overburden, which was leveled afterwards. The total area of disturbed landscape covers more than 6000 ha (Frouz et al. 2006). The overburden consisted mainly of alkaline tertiary clay with predominance of illite and kaolinite (Frouz et al. 2013). The mean annual precipitation is $650 \mathrm{~mm}$, and the mean annual temperature is $6.8^{\circ} \mathrm{C}$.

The spoil heap was covered by a mosaic of reclaimed forest monoculture plots with various tree species of similar age $(30-40$ years; Suppl. Fig. S1). Several parts of the heap were covered by spontaneously developed vegetation. For the purpose of this study, stands of four tree species underlain by the same overburden material were chosen: reclaimed sites planted with oak (Quercus robur), alder (Alnus glutinosa), and spruce (Picea omorica), and an unreclaimed site with predominance of naturally developed willow (Salix caprea). The understory was comprised of Calamagrostis at all sites, Fragaria vesca at the oak and willow sites, Festuca ovina at the willow site, and Elytrigia repens and Urtica dioica at the alder site. The sites were chosen so that they were, at maximum, 100 m apart. An exception was the willow site, which was located approximately $1 \mathrm{~km}$ away from the other sites. The sites were 1 to 10 ha large and the experiment was conducted on 1 to 2 ha large plots. Soil chemical properties of individual sites are presented in Table 1.

At each study plot, litter of the dominant tree species was collected in litter traps at the start of litter fall in 2012. Litter traps were installed in three replications in randomly chosen 
subplots (Suppl. Fig. S1). Litter of Calamagrostis was collected as standing dead biomass at the time of its senescence in three randomly chosen subplots at a 20 years' old site covered solely by the grass (Suppl. Fig. S1). All litter was dried, cut if necessary (in case of Calamagrostis) and mixed. Litter was then stored at room temperature until the experiment started. Litter material was placed into nylon litterbags $(5 \times 10 \mathrm{~cm})$ with a mesh size of $42 \mu \mathrm{m}$ so that a potential mixing with allochthonous material was minimized and the access of microbiota and microfauna enabled. In March 2013, litterbags, containing $2.5 \mathrm{~g}$ of tree litter, were placed within the top of the litter horizon at the respective subplot of collection (twelve replicates per site). Litterbags with Calamagrostis litter were placed at all study plots also within the litter horizon constituted of the respective tree litter. This was possible as the chosen sites were rather sparsely covered by understory, occurring in distinct patches. We avoided such patches and used subplots that were not covered by understory for the application of the litterbags. In case of the natural succession site, the litter horizon was predominantly constituted of willow litter. From each subplot, one litterbag filled with the respective tree species litter and one litterbag with Calamagrostis litter were collected after three, seven, and twelve months. This approach yielded three replicates per sampling time and plant species.

Sample preparation

After each litter collection, decomposed litter was freeze-dried, weighed, and separated for chemical and microbial analyses. Samples for DNA extraction (see below) were homogenized, frozen and stored at $-80{ }^{\circ} \mathrm{C}$ until processed. The rest of decomposed litter was homogenized and milled. Because of the presence of dust and soil particles in the litterbags, litter material was also used for the determination of OM contents by loss on ignition 
(incubation at $550^{\circ} \mathrm{C}$ for $6 \mathrm{~h}$ ). Organic matter contents in the incubated samples were then used for calculating the OM mass loss during the experiment.

\section{Chemical analyses}

The $\mathrm{C}$ and $\mathrm{N}$ contents of initial and all stages of decomposed litter were determined on a NC 2100 soil analyzer (Thermo-Quest Italia S.p.A.) via dry combustion.

Thermochemolysis-GC-MS was used to determine lignin chemistry (Sampedro et al. 2009). The contents of the lignin-related structures guaiacyl, syringyl, and hydroxyphenyl and non-assigned aromatic structures were determined in four replicates in all stages of decomposition from initial litter to litter after one year of decomposition. After the treatment with an excess of tetramethylammonium hydroxide (TMAH, 25\% aqueous solution), the samples were placed on wolfram wire spirals and dried in a desiccator. Pyrolysis was performed with a PYR-01 pyrolyzer (Labio, Czech Republic) directly in the injector of a GCMS (Varian 3400/Finnigan ITS 40 ion trap detector) as described previously (Frouz et al. 2015). The pyrolysis products were identified by interpreting the fragmentation patterns as well as by comparing their mass spectra with the NIST02 library. The relative peak areas of pyrolysis products were recalculated according to the exact sample weight.

The quality of total SOM was assessed using NMR and FTIR spectroscopy. NMR spectroscopy was used for initial tree litter and tree litter from the end of the experiment. NMR spectra were measured with a Bruker Avance III 400 MHz (9.4 T) spectrometer (Bruker BioSpin $\mathrm{GmbH}$ ). Each sample was spun in a $3.2 \mathrm{~mm}$ wide zircon-oxide rotor at $5.0 \mathrm{kHz}$. A standard CP/MAS ${ }^{13} \mathrm{C}\left\{{ }^{1} \mathrm{H}\right\}$ pulse sequence was employed using 1 s relaxation delay and a ${ }^{1} \mathrm{H}$ ramp pulse with a contact time of $1 \mathrm{~ms}$. The spectra were processed with a line broadening of $50 \mathrm{~Hz}$, phase adjusted, and baseline corrected. The following chemical shift regions were considered: 0-50 ppm (alkyl-C, i.e., aliphatic components), 50-110 ppm (O/N-alkyl-C, i.e., carbohydrates), 110-160 ppm (aryl-C, i.e. aromatic components) and 160-220 ppm 
(carboxylic-C). Additionally, the alkyl-C/O/N-alkyl-C ratio as an indicator of the degree of decomposition (Baldock et al. 1997) was calculated.

Infrared spectra of all samples were obtained with a Bruker VERTEX 70 series FTIR spectrometer (Bruker Optics, Germany) equipped with a horizontal attenuated total reflectance (ATR) sampling accessory. The samples were inserted directly on the ATR crystal, and a MIRacle high-pressure digital clamp was used to achieve even distribution and contact between the sample and crystal. Each spectrum consisted of 65 averaged absorbance measurements between 4000 and $650 \mathrm{~cm}^{-1}$, with a $4 \mathrm{~cm}^{-1}$ resolution. To minimize the effect of sample contamination with mineral particles, whose absorbance interferes with the absorbance bands assigned mainly to polysaccharides (Dawson and Hillier 2010), spectra were transformed with peak normalization at $3000 \mathrm{~cm}^{-1}$ and second derivative using the Unscrambler software (CAMO, Norway). Only measurements between 2966 and $2700 \mathrm{~cm}^{-1}$ and 1800 and $1190 \mathrm{~cm}^{-1}$ were used for analysis that was focused on absorption bands assigned to phenolic and aliphatic structures according to Artz et al. (2008).

\section{Microbial analyses}

We conducted PLFA analysis to estimate the composition of main soil microbial groups developed on litter during its decomposition. Litter samples were extracted using a chloroform-methanol-phosphate buffer mixture (1:2:0.8). Lipids were then separated with solid-phase extraction cartridges (LiChrolut Si 60, Merck) and the phospholipid fraction was subjected to mild alkaline methanolysis (Šnajdr et al. 2008). The free methyl esters of the PLFAs were analyzed using GC-MS (450-GC, 240-MS ion trap detector, Varian, Walnut Creek, CA, USA). Bacterial biomass was quantified as the sum of 10Me-16:0, 10Me-17:0, 10Me-18:0 indicating actinobacteria; i14:0, i15:0, a15:0, i16:0, i17:0, a17:0 indicating gram-

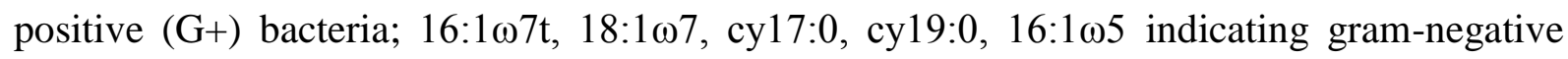
(G-) bacteria, and unspecific 15:0, 16:1 19, 17:0. Fungal biomass was quantified based on the 
content of $18: 2 \omega 6,9$. The fungal/bacterial ratio $(\mathrm{F}: \mathrm{B})$ was calculated as the ratio of fungal and bacterial PLFA.

DNA from each sample was extracted using the modified method of Miller (SagovaMareckova et al. 2008). Briefly, $180 \mathrm{mg}$ of soil were incubated with $1 \mathrm{M} \mathrm{CaCO}_{3}$ solution for 1 hour and subsequently extracted by the phenol-chloroform method. DNA extracts were purified using the Geneclean Turbo Kit (MP Biomedicals, Santa Ana, CA) and stored at -20 ${ }^{\circ} \mathrm{C}$ until further use. For microbial community analysis, PCR amplification of the fungal ITS2 region from DNA was performed using barcoded gITS7 and ITS4 primers (Ihrmark et al. 2012) as described previously (Žifčáková et al. 2016). The V4 region of bacterial 16S rRNA was amplified using the barcoded primers 515F and 806R (Caporaso et al. 2012). PCR was performed in triplicates for each sample as recommended by Schöler et al. (2017), and resulting amplicons were purified, pooled, and subjected to sequencing on the Illumina MiSeq. The presence of contaminant sequences was excluded using appropriate controls.

Processing of the amplicon sequencing data was done using the pipeline SEED 2.0.3 (Větrovský and Baldrian 2013) as described previously (Žifč́áková et al. 2016). The processing included several steps including quality filtering (adapter trimming, quality and length filtering, removal of chimeric sequences and sequences not matching the target), clustering, and identification as recommended by Vestergaard et al. (2017). Sequences identified as non-bacterial or non-fungal were discarded. Fungal samples were subsampled to equal numbers of randomly chosen sequences (5533 sequences per sample). Bacterial sequences were subsampled to median (12305 sequences per sample) where possible, samples with lower sequence counts were analyzed unchanged (Cárcer et al. 2011). Sequence data have been deposited in the MG RAST public database under accession numbers 367006 (fungi) and 366980 (bacteria) (Meyer et al. 2008). 
Relationships between individual properties (Mass remaining, $\mathrm{C}$ and $\mathrm{N}$ contents, $\mathrm{C}: \mathrm{N}$ ratio, lignin content and PLFA) were evaluated using multiple regression and correlation coefficients. Computations were made using the statistical program Statistica 13.

Data from PLFA analysis and FTIR spectroscopy were subjected to principal component analysis (PCA). Computations were done using the statistical program Canoco 4.5. In microbial community analyses, only OTUs that were more abundant than $0.5 \%$ in at least two of three replicates were considered. The composition of bacterial and fungal communities at individual sites was visualized using non-metric multidimensional scaling (NMDS) based on Bray-Curtis similarities of Hellinger-transformed data at OTU level and environmental variables (time, $\mathrm{C}, \mathrm{N}$ ) were fitted as vectors using the envfit function ( $\mathrm{R}$, 'vegan' library). The differences among microbial communities from different tree stands, litter types, and time points were tested using ANOSIM. The effects of environmental variables on microbial communities' properties were tested using PERMANOVA. Statistical tests were performed using R v. 3.2.5 (R Development Core Team 2016).

\section{Results}

Litter mass loss and $C$ and $N$ contents

Litter mass decreased most rapidly in the first three months for oak, alder, and willow litter (Fig. 1a). Only spruce litter mass did not substantially decrease during the first three months of the experiment and it lost least of its mass as compared to the other species, whereas alder decomposed most rapidly (Fig. 1a).

Calamagrostis litter mass decreased with time at all sites (Fig. 1b) without differences between sites after three months. From the seventh month, Calamagrostis decomposed faster 
at alder and willow sites than at spruce and oak sites (Fig. 1b). According to multiple regression, decomposition duration and site of exposure together explained $37 \%$ of Calamagrostis mass loss.

Spruce litter had the highest $\mathrm{C}$ content from all observed tree species (Table 1). The $\mathrm{C}: \mathrm{N}$ ratios decreased as the litter decomposed (Table 2). Overall, the highest $\mathrm{N}$ content and the lowest $\mathrm{C}: \mathrm{N}$ ratio was recorded for alder litter and the lowest $\mathrm{N}$ content and the highest $\mathrm{C}: \mathrm{N}$ ratio was found in spruce litter (Tables 1 and 2).

The Calamagrostis litter maintained a higher C content at spruce (46-47\%) and willow (45-47 \%) sites than at alder (40-43\%) and oak (41-44\%) sites during decomposition. The $\mathrm{N}$ content of Calamagrostis differed only at the alder site, where it was higher than at the other sites, the C:N ratio being lower (Table 2). As for all tree litter, C:N decreased during decomposition (Table 2).

\section{Lignin chemistry}

Spruce litter had the highest and alder litter the lowest proportion of all lignin-related structures during the whole duration of the decomposition experiment (Fig. 2a). Lignin in the alder litter decomposed most readily as only the content of syringyl units did not substantially change during decomposition, the relative content of aromatic components of the willow litter even slightly increased (Fig. 2a).

Overall, lignin-related structures in Calamagrostis litter decreased with time at all sites (Fig. 2b), most readily in the litter incubated at alder and willow sites (Fig. 2b). Only exception to this pattern was an increase at the oak site at the end of the incubation.

\section{Chemical composition as evaluated by NMR and FTIR spectroscopy}


The NMR spectroscopy revealed almost no change in chemical composition of tree litter after the one-year decomposition (Table 3). Only alder litter showed a relative increase in the content of O/N-alkyl-C and a decrease in alkyl-C (Suppl. Fig. S2).

According to FTIR spectroscopy and independent of sampling time, spruce litter had higher absorption intensities of the bands assigned to waxes and lipids (Fig. 3), while oak and alder inclined to have higher absorption intensities of the bands assigned to lignin.

Litter of Calamagrostis had lower absorption intensities of the bands assigned to lignin as compared to the tree litter (Fig. 3). The Calamagrostis litter changed its composition at the alder site the most.

\section{Litter-associated microorganisms}

The highest microbial biomass (PLFA total) was observed on oak litter after 3 and 7 months of decomposition (Fig. 4a). Spruce litter showed the highest F:B ratio that increased with time, while the F:B ratio on oak and willow litter was intermediate and low on alder litter, decreasing with time in all three litters (Fig. 4a). No clear trend in the development of the F:B ratio was observed in Calamagrostis litter, but it was always highest at the willow and lowest at the alder sites (Fig. 4b).

Fungal sequences clustered into 8356 OTUs, of which 5200 were singletons. Community composition was significantly different (ANOSIM, P <0.0001) under different trees, on different litter types, as well as at different time points, with tree stand having the strongest effect and the duration of decomposition the weakest. According to PERMANOVA, litter type $\left(\mathrm{R}^{2}=0.35, \mathrm{P}<0.001\right)$ had the major effect on fungal community composition, followed by tree site $\left(\mathrm{R}^{2}=0.19, \mathrm{P}<0.001\right), \mathrm{C}$ content $\left(\mathrm{R}^{2}=0.03, \mathrm{P}<0.001\right)$, time $\left(\mathrm{R}^{2}=0.02, \mathrm{P}\right.$ $<0.001), \mathrm{C}: \mathrm{N}$ ratio, and $\mathrm{N}\left(\mathrm{R}^{2}=0.017\right.$ and 0.016 , respectively, $\left.\mathrm{P}<0.001\right)$. Fungal communities in all samples were dominated by Ascomycota, except for the Calamagrostis samples from the 
willow site where Basidiomycota were the most abundant phylum, representing up to $85 \%$ of all sequences. On the genus level, fungal communities were heterogeneous among different trees, litter types, and time points (Suppl. Fig. S3). The NMDS showed apparent clustering of communities from alder, willow, and oak stands and their respective litters (Fig. 5), with willow being the most distinct. The communities from Calamagrostis litter at all sites were more similar to each other and to communities on spruce litter. The majority of fungi in all samples were identified as saprotrophs (Suppl. Fig. S4). Bacterial sequences were grouped into 17339 OTUs, of which 8933 were singletons. Bacterial communities were significantly different (ANOSIM, P <0.0001) under different trees, on different litter types, and at different time points (Suppl. Fig. S5). Litter type had the strongest effect on bacterial community composition (PERMANOVA, $\left.\mathrm{R}^{2}=0.23, \mathrm{P}<0.001\right)$, followed by $\mathrm{C}$ content $\left(\mathrm{R}^{2}=0.09, \mathrm{P}\right.$ $<0.001)$, tree stand $\left(\mathrm{R}^{2}=0.08, \mathrm{P}<0.001\right)$, time $\left(\mathrm{R}^{2}=0.03, \mathrm{P}<0.01\right)$, and $\mathrm{N}\left(\mathrm{R}^{2}=0.018 \mathrm{P}<0.05\right)$. The most abundant bacterial phylum in all samples was Proteobacteria, constituting 53\% of all sequences, followed by Bacteriodetes (22\%), and Actinobacteria (13\%). In contrast to fungi, NMDS did not reveal any apparent clustering of bacterial communities (Fig. 5).

\section{Relationships between litter characteristics}

Overall, litter decomposition correlated positively with $\mathrm{N}$ content and correlated negatively with $\mathrm{C}$ content and $\mathrm{C}: \mathrm{N}$ ratio (Table 4). Bacterial abundance (determined as PLFA bacteria $_{\text {) }}$ correlated positively with $\mathrm{N}$ content and correlated negatively with $\mathrm{C}$ content and $\mathrm{C}: \mathrm{N}$ ratio (Table 4).

Calamagrostis litter decomposition correlated positively with $\mathrm{N}$ content and microbial community abundance and correlated negatively with $\mathrm{C}: \mathrm{N}$ ratio and lignin content (Table 3 ).

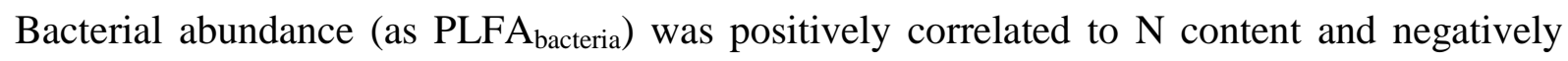
correlated to lignin content (Table 4). 


\section{Discussion}

Tree litter decomposition and associated microbial community development follow established patterns

Our results from the analyses of tree species litter reflect the well-known differences in decomposition patterns between coniferous and broadleaf litter (e.g. McClaugherty et al. 1985; Lorenz et al. 2000; Berg and McClaugherty 2008; Prescott 2010), where the mass of broadleaf litter decreased more quickly (Fig. 1a). In contrast to broadleaf litter, spruce litter did not show any substantial mass loss in the first three months of the incubation (Fig. 1a). Higher contents of surface waxes (Fig. 3) on the outer parts of the needles, forming a barrier for decomposers (Lorenz et al. 2004; Cotrufo et al. 2009), and a higher initial lignin content (Fig. 2a) were probably the main reason for the absence of the rapid OM disappearance observed for all broadleaf litters, predominantly during the first three months of decomposition. These decomposition patterns were in accordance with the often established negative correlation of mass loss with initial litter $\mathrm{C}: \mathrm{N}$ ratios (Tables 2 and 4; Taylor et al. 1989).

The chemical composition of all tree litters did not change substantially during the observed period. Only alder litter showed a relatively sharp decline in the content of aliphatic components. This decline is surprising because aliphatic components commonly relatively increase as litter decomposition proceeds (e.g. Almendros et al. 2000; Cepáková and Frouz 2015). We do not have a sound explanation for this observation but we suspect a relation to the low $\mathrm{C}$ : $\mathrm{N}$ ratio and high nutrient contents of alder litter (Tables 1 and 2), probably resulting in a rapid decomposition also of usually more 'recalcitrant' compounds in the presence of easily available substrates (Marschner et al. 2008). This is perhaps also the reason why alder 
litter had the highest mass loss at the end of the decomposition experiment (Fig. 1a). Litter decomposition of spruce and oak proceeded according to the expected patterns (Berg and McClaugherty 2008), demonstrated by an increase of alkyl-C/O/N-alkyl-C ratios (Table 3).

During tree litter decomposition, the greatest difference in the composition of microbial communities developed between litters of evergreen spruce and broadleaf alder, oak, and willow (Fig. 4a). The F:B ratio was highest in spruce litter and even increased during its decomposition, confirming the importance of fungi in decomposing needle litter (Baldrian et al. 2008). In contrast, the F:B ratio decreased with proceeding decomposition in all broadleaf litter (Fig. 4a), likely due to a litter chemical structure more prone to decomposition. The trend of high fungal abundance in the initial stages of litter decomposition followed by the increase of bacteria during decomposition, which was reported previously from other litters (Šnajdr et al. 2011; Urbanová et al. 2014), is in line with the decrease of litter C:N ratios. Based on these patterns, we expected Calamagrostis litter to decompose similarly as the tree litter at the respective sites.

\section{Understory litter decomposition as affected by dominant tree species}

Although the mass loss of Calamagrostis litter was positively correlated with its $\mathrm{N}$ content and negatively with its $\mathrm{C}: \mathrm{N}$ ratio and lignin content (well established key predictors of litter decomposition; Table 4; Melillo et al. 1982; Hobbie et al. 2006), different courses of Calamagrostis mass loss between the sites indicated an influence of additional factors on litter decomposition. These factors were most probably mediated by the dominant tree species at the respective sites, either via nutrients or inhibitors released from their litter or through their effect on microclimate or litter microbiota (Urbanová et al. 2015). This was indicated by Calamagrostis litter decomposing least at the spruce and oak sites, where also the dominant tree litter decomposed more slowly than litter at the other two sites (Fig. 1a, b). However, 
because these site-dependent differences in Calamagrostis decomposition did not become apparent immediately (Fig. 1b), it seems that the effect of tree site is manifested with some delay (as also observed by Wickings et al. (2012)). Until then, the initially steep and uniform decrease in Calamagrostis mass across sites (Fig. 1b) was mainly driven by initial Calamagrostis chemistry, where the labile litter fraction, i.e. DOM (Don and Kalbitz 2005; Uselman et al. 2012), and bioavailable compounds that are readily utilized by soil microorganisms (mainly by fungi and bacteria; Berg and McClaugherty 2008) quickly decrease.

After this initial phase (from the seventh month of our experiment), we assume that the decomposer communities at the respective study sites took at least partly control over the decomposition process. Except for the alder site, where the F:B ratio for Calamagrostis litter continuously decreased with time until the end of the incubation, it peaked in the seventh month at all other sites (Fig. 4b). We assume that this peak is a consequence of a depletion of free carbohydrates that is followed by a demand for breaking lignocellulose complexes (Osono 2007) to assure microbial accessibility to protected carbohydrates. Calamagrostis contains a relatively high amount of carbohydrates (Fig. 3; Frouz et al. 2011; Angst et al. 2017) and a large part may be associated with lignin (cf. Angst et al. 2016). Because fungi are thought to be the most important degraders of lignin (e.g. Hatakka 1994), their abundance increases relative to bacteria when easily decomposable compounds are depleted, which may explain the peak of fungal abundance in the seventh month. After fungi had (at least partly) broken up lignocellulose complexes and made additional carbohydrates accessible, bacterial growth was favored and fungal abundance relatively decreased again. The different mass losses among the sites are thus likely an interaction of inherent Calamagrostis litter chemistry and the adaption of the resident microbial community to this chemistry at the respective site. This adaption seemed to be greatest at the willow site, where the F:B ratio was highly dissimilar to the other sites and also to the willow litter itself (Fig. 4a, b). Willow probably 
favors the abundance of fungi because the Calamagrostis litter at this site was dominated by Agaricales saprotrophs (basidiomycetes) that even increased with time (Suppl. Figs. S3 and S4). Basidiomycetes are proposed to be effective decomposers of recalcitrant litter compounds (Osono 2007; Treseder et al. 2014), likely explaining why Calamagrostis at this site showed the highest mass loss in the seventh month of all observed sites (Fig. 1b).

However, as mentioned above, the peak in fungal abundance in the seventh month of the experiment, occurring at the oak, spruce, and willow site, could not be observed at the alder site. The alder site was characterized by an extraordinarily high supply of $\mathrm{N}$ because of the occurrence of $\mathrm{N}$-fixing symbionts and a typically high $\mathrm{N}$ content in alder litter (Wheeler 1971; Cepáková et al. 2016). These two factors likely provided a source of external $\mathrm{N}$ also for Calamagrostis litter decomposition. A sufficient amount of $\mathrm{N}$ was also reflected in a significantly higher $\mathrm{N}$ content in Calamagrostis litter that was apparent from the seventh month of the experiment at this site. Several authors (e.g., Voříšková et al. 2011; Šnajdr et al. 2013; Chomel et al. 2016) claimed that $\mathrm{N}$ increases fungal biomass in litter. This was not observed in the present study. External $\mathrm{N}$ rather supported bacterial growth (as indicated by PLFA data; Fig. 4b). As $\mathrm{N}$ is a well-known limiting factor of litter decomposition (Berg and McClaugherty 2008), its abundance was most probably the main driver why Calamagrostis decomposed most readily at the alder site (together with the willow site), supporting the efficiency of the microbial community in disrupting more recalcitrant litter components. Unlike previous studies (Berg 2000; Carreiro et al. 2000), where high N contents were described as inhibitor of lignin decomposition because of their negative effect on ligninolytic enzyme activity, our results did not indicate a negative effect on Calamagrostis lignin decomposition at the alder site.

In accordance with the highest observed mass loss, Calamagrostis lignin decomposition (Fig. 2b) was fastest at the willow site, where the fungal community developed most intensely in the Calamagrostis litter as compared to the other sites (Fig. 4b). Opposite to 
that, Calamagrostis lignin at the spruce site, where the fungal community was also broadly developed (Fig. 4a), decomposed more slowly. This may be explained by less favorable conditions for microbial activity at the spruce site, likely caused by higher contents of polyphenols in the soil originating from needle litter (Lorenz et al. 2000). Polyphenols are known as potential inhibitors of decomposition processes, e.g. suppressing spore germination or hyphal growth (Hättenschwiler and Vitousek 2000).

Based on our results, we infer that litter chemistry constitutes a major factor responsible for decomposition and microbial community composition (Urbanová et al. 2014, 2015), which shows a successional development (Voř́išková and Baldrian 2013; LópezMondéjar et al. 2015; Tláskal et al. 2016). The site effect was, however, strong enough to cause significant differences in the composition and development of microbial communities associated with Calamagrostis litter (and its decomposition), showing that species identity had a stronger effect than environmental filtering by litter chemistry. Our results may be transferable to sites with similar management and climate, and useful for future studies aiming at obtaining a mechanistic understanding about tree species effects on litter decomposition.

\section{Conclusions}

Although the chemistry of litter is a major factor in its decomposition, dominant tree species likely affected the microbial community (both its biomass and composition) and soil environment to such an extent that the decomposition of the same understory litter significantly differed between the common garden sites after our one-year experiment. This implies that dominant trees determine not only the fate of their own litter but also affect litter decomposition of their understory - both in terms of litter chemistry and the microorganisms involved. However, the tree species effect does not seem to be utterly predictable. While, in 
accordance with our hypothesis, Calamagrostis litter seemed to be affected by tree litter chemistry, showing higher $\mathrm{N}$ contents at the alder site (probably largely influenced by N-rich alder litter), and a slow decomposition at the spruce site (probably influenced by leachates from low-quality spruce litter), the microbial community development on Calamagrostis litter did not proceed as expected. Although the Calamagrostis litter at the alder site was indeed colonized by relatively more bacteria, the microbial community of Calamagrostis litter neither reflected the high fungal abundance of the spruce litter nor corresponded to that associated with the litter of oak and willow at the respective site. Yet, the microbial community on Calamagrostis litter largely differed between the sites investigated. These results suggest that the co-occurrence of tree and understory litter in the forest floor leads to the development of distinct microbial communities, differing from those that could be expected when considering inherent litter chemistry only.

Conflict of Interest: The authors declare that they have no conflict of interest.

\section{References}

Almendros G, Dorado J, González-Vila FJ, Blanco MJ, Lankes, U (2000) ${ }^{13} \mathrm{C}$ NMR assessment of decomposition patterns during composting of forest and shrub biomass. Soil Biol Biochem 32:793-804. doi: 10.1016/S0038-0717(99)00202-3

Angst G, Heinrich L, Kögel-Knabner I, Mueller CW (2016) The fate of cutin and suberin of decaying leaves, needles and roots - Inferences from the initial decomposition of bound fatty acids. Org Geochem 95:81-92. doi: 10.1016/j.orggeochem.2016.02.006

Angst G, Messinger J, Greiner M, Häusler W, Hertel D, Kirfel K, Kögel-Knabner I, Leuschner C, Rethemeyer J, Mueller CW (2018) Soil organic carbon stocks in topsoil and subsoil controlled by parent material, carbon input in the rhizosphere, and microbial- 
derived compounds. Soil Biol Biochem 122:19-30. doi:

10.1016/J.SOILBIO.2018.03.026

Angst G, Mueller KE, Eissenstat DM, Trumbore S, Freeman KH, Hobbie SE, Chorover J, Oleksyn J, Reich PB, Mueller CW (2019) Soil organic carbon stability in forests: distinct effects of tree species identity and traits. Glob Chang Biol. doi: 10.1111/gcb.14548

Angst Š, Cajthaml T, Angst G, Šimáčková H, Brus J, Frouz J (2017) Retention of dead standing plant biomass (marcescence) increases subsequent litter decomposition in the soil organic layer. Plant Soil. doi: 10.1007/s11104-017-3318-6

Artz RRE, Chapman SJ, Jean Robertson AH, Potts JM, Laggoun-Défarge F, Gogo S, Comont L, Disnar JR, Francez AJ (2008) FTIR spectroscopy can be used as a screening tool for organic matter quality in regenerating cutover peatlands. Soil Biol Biochem 40:515-527. doi: 10.1016/j.soilbio.2007.09.019

Baldock JA, Oades JM, Nelson PN, Skene TM, Golchin A, Clarke P (1997) Assessing the extent of decomposition of natural organic materials using solid-state ${ }^{13} \mathrm{C}$ NMR spectroscopy. Aust J Soil Res 35:1061-1083. doi: 10.1071/s97004

Baldrian P, Trögl J, Frouz J, Šnajdr J, Valášková V, Merhautová V, Cajthaml T, Herinková J (2008) Enzyme activities and microbial biomass in topsoil layer during spontaneous succession in spoil heaps after brown coal mining. Soil Biol Biochem 40:2107-2115. doi: 10.1016/j.soilbio.2008.02.019

Bauhus J, Paré D, Côté L (1998) Effects of tree species, stand age and soil type on soil microbial biomass and its activity in a southern boreal forest. Soil Biol Biochem 30:1077-1089. doi: 10.1016/S0038-0717(97)00213-7

Berg B (2000) Litter decomposition and organic matter turnover in northern forest soils. For Ecol Manage 133:13-22.

Berg B, McClaugherty C (2008) Plant litter decomposition, humus formation,carbon sequestration. Springer Berlin Heidelberg, Heidelberg 
Caporaso JG, Lauber CL, Walters WA, Berg-Lyons D, Huntley J, Fierer N, Owens SM, Betley J, Fraser L, Bauer M, Gormley N, Gilbert JA, Smith G, Knight R (2012) Ultrahigh-throughput microbial community analysis on the Illumina HiSeq and MiSeq platforms. ISME J 6:1621-1624. doi: 10.1038/ismej.2012.8

Cárcer DA de, Denman SE, McSweeney C, Morrison M (2011) Evaluation of subsamplingbased normalization strategies for tagged high-throughput sequencing data sets from gut microbiomes. Appl Environ Microbiol 77:8795-8. doi: 10.1128/AEM.05491-11

Carreiro MM, Sinsabaugh RL, Repert DA, Parkhurst DF (2000) Microbial Enzyme Shifts Explain Litter Decay Responses To Simulated Nitrogen Deposition. Ecology 81:2359_ 2365. doi: 10.1890/0012-9658(2000)081[2359:MESELD]2.0.CO;2

Cepáková Š, Frouz J (2015) Changes in chemical composition of litter during decomposition: a review of published ${ }^{13} \mathrm{C}$ NMR spectra. J Soil Sci Plant Nutr 15:805-815.

Cepáková Šs, Tošner Z, Frouz J (2016) The effect of tree species on seasonal fluctuations in water-soluble and hot water-extractable organic matter at post-mining sites. Geoderma 275:19-27. doi: 10.1016/j.geoderma.2016.04.006

Chodak M, Niklińska M (2010) The effect of different tree species on the chemical and microbial properties of reclaimed mine soils. Biol Fertil Soils 46:555-566. doi: $10.1007 / \mathrm{s} 00374-010-0462-\mathrm{z}$

Chomel M, Guittonny-Larchevêque M, DesRochers A, Baldy V (2016) Effect of mixing herbaceous litter with tree litters on decomposition and $\mathrm{N}$ release in boreal plantations. Plant Soil 398:229-241. doi: 10.1007/s11104-015-2648-5

Cotrufo MF, Galdo I Del, Piermatteo D (2009) Litter decomposition: concepts, methods, and future perspectives. Soil Carbon Dyn 76-91. doi: 10.1017/CBO9780511711794.006

Dawson LA, Hillier S (2010) Measurement of soil characteristics for forensic applications. Surf Interface Anal 42:363-377. doi: 10.1002/sia.3315

Don A, Kalbitz K (2005) Amounts and degradability of dissolved organic carbon from foliar 
litter at different decomposition stages. Soil Biol Biochem 37:2171-2179. doi:

10.1016/j.soilbio.2005.03.019

Frouz J, Cajthaml T, Mudrák O (2011) The effect of lignin photodegradation on decomposability of Calamagrostis epigeios grass litter. Biodegradation 22:1247-1254. doi: 10.1007/s10532-011-9479-8

Frouz J, Elhottová D, Kuráž V, Šourková M (2006) Effects of soil macrofauna on other soil biota and soil formation in reclaimed and unreclaimed post mining sites: Results of a field microcosm experiment. Appl Soil Ecol 33:308-320. doi:

10.1016/j.apsoil.2005.11.001

Frouz J, Livečková M, Albrechtová J, Chroňáková A, Cajthaml T, Pižl V, Háněl L, Starý J, Baldrian P, Lhotáková Z, Šimáčková H, Cepáková Š (2013) Is the effect of trees on soil properties mediated by soil fauna? A case study from post-mining sites. For Ecol Manage. doi: 10.1016/j.foreco.2013.02.013

Frouz J, Prach K, Pižl V, Háněl L, Starý J, Tajovský K, Materna J, Balík V, Kalčík J, Řehounková K (2008) Interactions between soil development, vegetation and soil fauna during spontaneous succession in post mining sites. Eur J Soil Biol 44:109-121. doi: 10.1016/j.ejsobi.2007.09.002

Frouz J, Špaldoňová A, Lhotáková Z, Cajthaml T (2015) Major mechanisms contributing to the macrofauna-mediated slow down of litter decomposition. Soil Biol Biochem 91:2331. doi: 10.1016/j.soilbio.2015.08.024

Gartner TB, Cardon ZG (2004) Decomposition dynamics in mixed-species leaf litter. Oikos 104:230-246. doi: 10.1111/j.0030-1299.2004.12738.x

Hatakka A (1994) Lignin-modifying enzymes from selected white-rot fungi: production and role in lignin degradation. FEMS Microbiol Rev 13:125-135.

Hättenschwiler S (2005) Effects of tree species diversity on litter quality and decomposition. For Divers Funct Temp boreal Syst 149-164. doi: 10.1007/3-540-26599-6 
Hättenschwiler S, Vitousek PM (2000) The role of polyphenols in terrestrial ecoystems nutrient cycling. Tree 15:238-243.

Hobbie SE, Ogdahl M, Chorover J, Chadwick OA, Oleksyn J, Zytkowiak R, Reich PB (2007) Tree species effects on soil organic matter dynamics: The role of soil cation composition. Ecosystems 10:999-1018. doi: 10.1007/s10021-007-9073-4

Hobbie SE, Reich PB, Oleksyn J, Ogdahl M, Zytkowiak R, Hale C, Karolewski P (2006) Tree Species Effects on Decomposition and Forest Floor Dynamics in a Common Garden. Ecology 87:2288-2297.

Hoorens B, Aerts R, Stroetenga M (2003) Does initial litter chemistry explain litter mixture effects on decomposition? Oecologia 137:578-586. doi: 10.1007/s00442-003-1365-6

Ihrmark K, Bödeker ITM, Cruz-Martinez K, Friberg H, Kubartova A, Schenck J, Strid Y, Stenlid J, Brandström-Durling M, Clemmensen KE, Lindahl BD (2012) New primers to amplify the fungal ITS2 region - evaluation by 454-sequencing of artificial and natural communities. FEMS Microbiol Ecol 82:666-677. doi: 10.1111/j.15746941.2012.01437.x

Kiikkilä O, Kitunen V, Smolander A (2011) Properties of dissolved organic matter derived from silver birch and Norway spruce stands: Degradability combined with chemical characteristics. Soil Biol Biochem 43:421-430. doi: 10.1016/J.SOILBIO.2010.11.011

Laganière J, Paré D, Bradley RL (2010) How does a tree species influence litter decomposition? Separating the relative contribution of litter quality, litter mixing, and forest floor conditions. Can J For Res 40:465-475. doi: 10.1139/X09-208

López-Mondéjar R, Voříšková J, Větrovský T, Baldrian P (2015) The bacterial community inhabiting temperate deciduous forests is vertically stratified and undergoes seasonal dynamics. Soil Biol Biochem 87:43-50. doi: 10.1016/j.soilbio.2015.04.008

Lorenz K, Preston CM, Krumrei S, Feger KH (2004) Decomposition of needle/leaf litter from Scots pine, black cherry, common oak and European beech at a conurbation forest site. 
Eur J For Res 123:177-188. doi: 10.1007/s10342-004-0025-7

Lorenz K, Preston CM, Raspe S, Morrison IK, Feger KH (2000) Litter decomposition and humus characteristics in Canadian and German spruce ecosystems: Information from tannin analysis and ${ }^{13} \mathrm{C}$ CPMAS NMR. Soil Biol Biochem 32:779-792. doi: 10.1016/S0038-0717(99)00201-1

Marschner B, Brodowski S, Dreves A, Gleixner G, Gude A, Grootes PM, Hamer U, Heim A, Jandl G, Ji R, Kaiser K, Kalbitz K, Kramer C, Leinweber P, Rethemeyer J, Schäffer A, Schmidt MWI, Schwark L, Wiesenberg GLB (2008) How relevant is recalcitrance for the stabilization of organic matter in soils? J Plant Nutr Soil Sci 171:91-110. doi: 10.1002/jpln.200700049

McClaugherty CA, Pastor J, Aber JD, Melillo JM (1985) Forest Litter Decomposition in Relation to Soil Nitrogen Dynamics and Litter Quality. Ecology 66:266-275. doi: $10.2307 / 1941327$

Melillo JM, Aber JD, Muratore JF (1982) Nitrogen and lignin control of hardwood leaf litter decomposition dynamics. Ecology 63:621-626. doi: 10.2307/1936780

Meyer F, Paarmann D, D’Souza M, Olson R, Glass EM, Kubal M, Paczian T, Rodriguez A, Stevens R, Wilke A, Wilkening J, Edwards RA (2008) The metagenomics RAST server - a public resource for the automatic phylogenetic and functional analysis of metagenomes. BMC Bioinformatics 9:386. doi: 10.1186/1471-2105-9-386

Mudrák O, Frouz J, Velichová V (2010) Understory vegetation in reclaimed and unreclaimed post-mining forest stands. Ecol Eng 36:783-790. doi: 10.1016/j.ecoleng.2010.02.003

Osono T (2007) Ecology of ligninolytic fungi associated with leaf litter decomposition. Ecol Res 22:955-974. doi: 10.1007/s11284-007-0390-Z

Prach K, Pyšek P, Bastl M (2001) Spontaneous vegetation succession in human-disturbed habitats: A pattern across seres. Appl Veg Sci 4:83-88. doi: 10.1111/j.1654109X.2001.tb00237.x 
Prescott CE (2010) Litter decomposition: What controls it and how can we alter it to sequester more carbon in forest soils? Biogeochemistry 101:133-149. doi: 10.1007/s10533-0109439-0

Qiao Y, Miao S, Silva LCR, Horwath WR (2014) Understory species regulate litter decomposition and accumulation of $\mathrm{C}$ and $\mathrm{N}$ in forest soils: A long-term dual-isotope experiment. For Ecol Manage 329:318-327. doi: 10.1016/j.foreco.2014.04.025

R Development Core Team (2016) R: A Language and Environment for Statistical Computing.

Rebele F, Lehmann C (2001) Biological flora of Central Europe: Calamagrostis epigejos (L.) Roth. Flora 196:325-344. doi: 10.1016/S0367-2530(17)30069-5

Reich PB, Oleksyn J, Modrzynski J, Mrozinski P, Hobbie SE, Eissenstat DM, Chorover J, Chadwick OA, Hale CM, Tjoelker MG (2005) Linking litter calcium, earthworms and soil properties: A common garden test with 14 tree species. Ecol Lett 8:811-818. doi: 10.1111/j.1461-0248.2005.00779.x

Sagova-Mareckova M, Cermak L, Novotna J, Plhackova K, Forstova J, Kopecky J (2008) Innovative methods for soil DNA purification tested in soils with widely differing characteristics. Appl Environ Microbiol 74:2902-7. doi: 10.1128/AEM.02161-07

Sampedro I, Cajthaml T, Marinari S, Petruccioli M, Grego S, D’Annibale A (2009) Organic matter transformation and detoxification in dry olive mill residue by the saprophytic fungus Paecilomyces farinosus. Process Biochem 44:216-225. doi: 10.1016/j.procbio.2008.10.016

Schöler A, Jacquiod S, Vestergaard G, Schulz S, Schloter M (2017) Analysis of soil microbial communities based on amplicon sequencing of marker genes. Biol Fertil Soils 53:485489. doi: 10.1007/s00374-017-1205-1

Shihan A, Hättenschwiler S, Milcu A, Joly FX, Santonja M, Fromin N (2017) Changes in soil microbial substrate utilization in response to altered litter diversity and precipitation in a 
Mediterranean shrubland. Biol Fertil Soils 53:171-185. doi: 10.1007/s00374-016-1166-9

Šnajdr J, Cajthaml T, Valášková V, Merhautová V, Petránková M, Spetz P, Leppänen K,

Baldrian P (2011) Transformation of Quercus petraea litter: Successive changes in litter chemistry are reflected in differential enzyme activity and changes in the microbial community composition. FEMS Microbiol Ecol 75:291-303. doi: 10.1111/j.15746941.2010.00999.x

Šnajdr J, Dobiášová P, Urbanová M, Petránková M, Cajthaml T, Frouz J, Baldrian P (2013) Dominant trees affect microbial community composition and activity in post-mining afforested soils. Soil Biol Biochem 56:105-115. doi: 10.1016/j.soilbio.2012.05.004 Šnajdr J, Valášková V, Merhautová V, Cajthaml T, Baldrian P (2008) Activity and spatial distribution of lignocellulose-degrading enzymes during forest soil colonization by saprotrophic basidiomycetes. Enzyme Microb Technol 43:186-192. doi:

10.1016/j.enzmictec.2007.11.008

Taylor BR, Parkinson D, Parsons WFJ (1989) Nitrogen and Lignin Content as Predictors of Litter Decay Rates: A Microcosm Test. Ecology 70:97-104. doi: 10.2307/1938416 Tláskal V, Voř́íšková J, Baldrian P (2016) Bacterial succession on decomposing leaf litter exhibits a specific occurrence pattern of cellulolytic taxa and potential decomposers of fungal mycelia. FEMS Microbiol Ecol 92:1-10. doi: 10.1093/femsec/iw177

Treseder KK, Bent E, Borneman J, McGuire KL (2014) Shifts in fungal communities during decomposition of boreal forest litter. Fungal Ecol 10:58-69. doi:

10.1016/j.funeco.2013.02.002

Urbanová M, Šnajdr J, Baldrian P (2015) Composition of fungal and bacterial communities in forest litter and soil is largely determined by dominant trees. Soil Biol Biochem 84:5364. doi: 10.1016/j.soilbio.2015.02.011

Urbanová M, Šnajdr J, Brabcová V, Merhautová V, Dobiášová P, Cajthaml T, Vaněk D, Frouz J, Šantrůčková H, Baldrian P (2014) Litter decomposition along a primary post- 
mining chronosequence. Biol Fertil Soils 50:827-837. doi: 10.1007/s00374-014-0905-z

Uselman SM, Qualls RG, Lilienfein J (2012) Quality of soluble organic C, N, and P produced by different types and species of litter: Root litter versus leaf litter. Soil Biol Biochem 54:57-67. doi: 10.1016/j.soilbio.2012.03.021

Vestergaard G, Schulz S, Schöler A, Schloter M (2017) Making big data smart-how to use metagenomics to understand soil quality. Biol Fertil Soils 53:479-484. doi: $10.1007 / \mathrm{s} 00374-017-1191-3$

Větrovský T, Baldrian P (2013) Analysis of soil fungal communities by amplicon pyrosequencing: current approaches to data analysis and the introduction of the pipeline SEED. Biol Fertil Soils 49:1027-1037. doi: 10.1007/s00374-013-0801-y

Vořŕšková J, Baldrian P (2013) Fungal community on decomposing leaf litter undergoes rapid successional changes. ISME J 7:477-86. doi: 10.1038/ismej.2012.116

Voř́šková J, Dobiášová P, Šnajdr J, Vaněk D, Cajthaml T, Šantrůčková H, Baldrian P (2011) Chemical composition of litter affects the growth and enzyme production by the saprotrophic basidiomycete Hypholoma fasciculare. Fungal Ecol 4:417-426. doi: 10.1016/j.funeco.2011.03.005

Wallenstein MD, Haddix ML, Ayres E, Steltzer H, Magrini-Bair KA, Paul EA (2013) Litter chemistry changes more rapidly when decomposed at home but converges during decomposition-transformation. Soil Biol Biochem 57:311-319. doi: 10.1016/j.soilbio.2012.09.027

Wheeler C (1971) Causation of diurnal changes in nitrogen fixation in nodules of Alnus glutinosa. New Phytol 70:487-495.

Wickings K, Grandy AS, Reed SC, Cleveland CC (2012) The origin of litter chemical complexity during decomposition. Ecol Lett 15:1180-8. doi: 10.1111/j.14610248.2012.01837.x

Zhao L, Hu YL, Lin GG, Gao YC, Fang YT, Zeng DH (2013) Mixing Effects of Understory 
Plant Litter on Decomposition and Nutrient Release of Tree Litter in Two Plantations in Northeast China. PLoS One 8:20-22. doi: 10.1371/journal.pone.0076334

Žifčáková L, Větrovský T, Howe A, Baldrian P (2016) Microbial activity in forest soil reflects the changes in ecosystem properties between summer and winter. Environ Microbiol 18:288-301. doi: 10.1111/1462-2920.13026 
Table 1 Soil chemical properties of individual plots at which the decomposition experiment was conducted (i.e., no soil data is displayed for the Calamagrostis sampling plot), and C and $\mathrm{N}$ contents of leaf litter examined in the experiment. Values presented in the table are means \pm SEM. Chemical soil properties are taken from studies of Frouz et al. (2013) and Šnajdr et al. (2013).

\begin{tabular}{|c|c|c|c|c|c|}
\hline & Understory & Coniferous & & Broadleaf & \\
\hline & $\begin{array}{c}\text { Calamagrostis } \\
\text { epigejos }\end{array}$ & Picea omorica & Quercus robur & Salix caprea & Alnus glutinosa \\
\hline $\mathrm{pH}$ & & $6.7 \pm 0.3$ & $6.9 \pm 0.4$ & $7.4 \pm 0.2$ & $6.6 \pm 0.3$ \\
\hline $\mathrm{C}_{\mathrm{ox}}\left(\mathrm{g} \mathrm{kg}^{-1}\right)$ & & $227 \pm 22$ & $187 \pm 35$ & $223 \pm 17$ & $162 \pm 19$ \\
\hline $\mathrm{N}\left(\mathrm{g} \mathrm{kg}^{-1}\right)$ & & $3.9 \pm 0.5$ & $4.4 \pm 0.1$ & $4.4 \pm 0.8$ & $5.4 \pm 1.0$ \\
\hline $\mathrm{P}\left(\mathrm{mg} \mathrm{kg}^{-1}\right)$ & & $13.8 \pm 1.7$ & $11.0 \pm 2.4$ & $12.3 \pm 0.4$ & $15.3 \pm 1.8$ \\
\hline $\mathrm{K}\left(\mathrm{mg} \mathrm{kg}^{-1}\right)$ & & $130 \pm 12.5$ & $148 \pm 23$ & $170 \pm 3.5$ & $242 \pm 31$ \\
\hline $\mathrm{C}_{\text {leaf }}\left(\mathrm{g} \mathrm{kg}^{-1}\right)$ & $428 \pm 0.2$ & $518 \pm 0.3$ & $484 \pm 0.0$ & $461 \pm 0.1$ & $486 \pm 0.5$ \\
\hline $\mathrm{N}_{\text {leaf }}\left(\mathrm{g} \mathrm{kg}^{-1}\right)$ & $5.9 \pm 0.3$ & $5.4 \pm 0.4$ & $12.9 \pm 0.5$ & $19.8 \pm 0.4$ & $24.3 \pm 0.2$ \\
\hline
\end{tabular}


Table 2 C:N ratio of initial litter of spruce, oak, willow, alder, and Calamagrostis and after three, seven, and twelve months of decomposition. Values are means \pm SEM.

\begin{tabular}{|c|c|c|}
\hline & $\begin{array}{c}\mathrm{C}: \mathrm{N} \text { ratio } \\
\text { trees }\end{array}$ & $\begin{array}{c}\text { C:N ratio } \\
\text { Calamagrostis }\end{array}$ \\
\hline \multicolumn{3}{|l|}{ Picea omorica } \\
\hline Initial & $96.8 \pm 7.9$ & $72.4 \pm 3.7$ \\
\hline Three months & $53.9 \pm 1.6$ & $60.4 \pm 2.7$ \\
\hline Seven months & $43.2 \pm 0.5$ & $41.3 \pm 0.2$ \\
\hline Twelve months & $41.4 \pm 1.2$ & $30.2 \pm 0.4$ \\
\hline \multicolumn{3}{|l|}{ Quercus robur } \\
\hline Initial & $37.5 \pm 1.4$ & $72.4 \pm 3.7$ \\
\hline Three months & $16.3 \pm 0.3$ & $77.1 \pm 2.6$ \\
\hline Seven months & $14.0 \pm 0.1$ & $43.5 \pm 0.3$ \\
\hline Twelve months & $16.6 \pm 0.0$ & $34.7 \pm 0.5$ \\
\hline \multicolumn{3}{|l|}{ Salix caprea } \\
\hline Initial & $23.3 \pm 0.5$ & $72.4 \pm 3.7$ \\
\hline Three months & $16.6 \pm 0.0$ & $53.4 \pm 2.0$ \\
\hline Seven months & $24.4 \pm 1.2$ & $43.9 \pm 2.7$ \\
\hline Twelve months & $20.9 \pm 0.3$ & $41.9 \pm 0.2$ \\
\hline \multicolumn{3}{|l|}{ Alnus glutinosa } \\
\hline Initial & $20.0 \pm 0.1$ & $72.4 \pm 3.7$ \\
\hline Three months & $16.6 \pm 0.0$ & $40.0 \pm 1.5$ \\
\hline Seven months & $13.9 \pm 0.1$ & $23.3 \pm 0.2$ \\
\hline Twelve months & $14.8 \pm 0.2$ & $20.8 \pm 0.4$ \\
\hline
\end{tabular}


Table 3 Relative contribution of peak areas (percent of total area) for different chemical shift regions (ppm) and ratio between specific spectral ranges determined by solid state ${ }^{13} \mathrm{C}$ CP/MAS NMR spectroscopy in initial leaves of spruce, oak, alder, and willow and after one year of decomposition.

\begin{tabular}{|c|c|c|c|c|c|}
\hline \multirow{2}{*}{ Litter type } & \multicolumn{4}{|c|}{ Chemical shift regions (ppm) } & \multirow[b]{2}{*}{$\begin{array}{c}\text { Alkyl-C / } \\
\text { O/N-alkyl-C }\end{array}$} \\
\hline & Alkyl-C & $\begin{array}{c}\text { O/N Alkyl- } \\
\text { C }\end{array}$ & Aryl-C & $\begin{array}{c}\text { Carboxyl- } \\
\text { C }\end{array}$ & \\
\hline \multicolumn{6}{|c|}{ Picea omorica } \\
\hline Initial & 20.8 & 57.9 & 13.7 & 7.6 & 0.36 \\
\hline Twelve months & 23.0 & 55.5 & 13.5 & 8.0 & 0.41 \\
\hline \multicolumn{6}{|c|}{ Quercus robur } \\
\hline Initial & 19.2 & 58.1 & 13.8 & 8.9 & 0.33 \\
\hline Twelve months & 20.0 & 52.9 & 16.1 & 11.1 & 0.38 \\
\hline \multicolumn{6}{|l|}{ Salix caprea } \\
\hline Initial & 29.0 & 49.5 & 11.8 & 9.7 & 0.58 \\
\hline Twelve months & 25.8 & 48.6 & 14.9 & 10.7 & 0.53 \\
\hline \multicolumn{6}{|c|}{ Alnus glutinosa } \\
\hline Initial & 30.5 & 46.4 & 13.1 & 10.0 & 0.66 \\
\hline Twelve months & 17.7 & 56.7 & 15.3 & 10.3 & 0.31 \\
\hline
\end{tabular}


Table 4 Correlations between determined parameters for all litter (Calamagrostis + tree litter independent of species; grey part of the table) and for Calamagrostis litter individually (white part of the table). Numbers of the first row correspond with numbered names of parameters in the first column. (n) indicates the number of measurements in the data set in the respective line. Only significant $r$ values $(\mathrm{P}<0.05)$ are shown. Bold numbers are significant after Bonferroni correction.

\begin{tabular}{|c|c|c|c|c|c|c|c|c|c|c|c|}
\hline \multirow[b]{3}{*}{ Litter parameters } & \multirow[b]{3}{*}{ (n) } & \multicolumn{10}{|c|}{$r$ values } \\
\hline & & \multicolumn{10}{|c|}{ Litter parameters } \\
\hline & & 1 & 2 & 3 & 4 & 5 & 6 & 7 & 8 & 9 & (n) \\
\hline 1 Mass remaining & 50 & - & 0.296 & -0.318 & 0.475 & & & & & & 107 \\
\hline 2 Carbon & 32 & & - & & & -0.288 & & -0.577 & & & 64 \\
\hline 3 Nitrogen & 32 & -0.646 & & - & -0.876 & -0.691 & & 0.436 & & -0.424 & 64 \\
\hline $4 \mathrm{C}: \mathrm{N}$ & 32 & 0.750 & & & - & 0.664 & & -0.553 & & & 64 \\
\hline 5 Lignin & 42 & 0.447 & & -0.405 & 0.463 & - & & & & & 95 \\
\hline 6 PLFA fungi & 12 & & & & & & - & & 0.871 & 0.904 & 24 \\
\hline 7 PLFA bacteria & 12 & & -0.727 & 0.780 & -0.637 & & & - & & & 24 \\
\hline 8 Total PLFA & 12 & -0.660 & & & & & & & - & & 24 \\
\hline $9 \mathrm{~F}: \mathrm{B}$ ratio & 12 & & & & & & & & & - & 24 \\
\hline
\end{tabular}



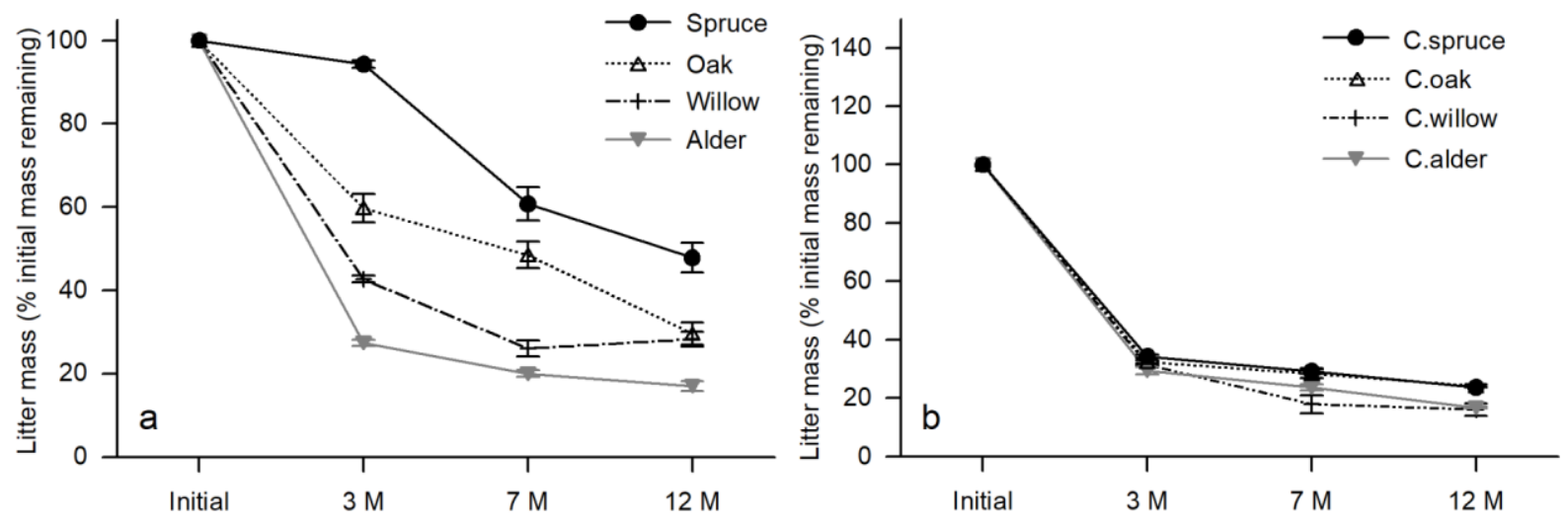

Fig. 1 Mass loss of (a) spruce, oak, willow, and alder litter during the one-year decomposition experiment and (b) mass loss of Calamagrostis litter that was placed at spruce (C.spruce), oak (C.oak), willow (C.willow), and alder (C.alder) sites for one year. Symbols represent means and bars represent SEM. 

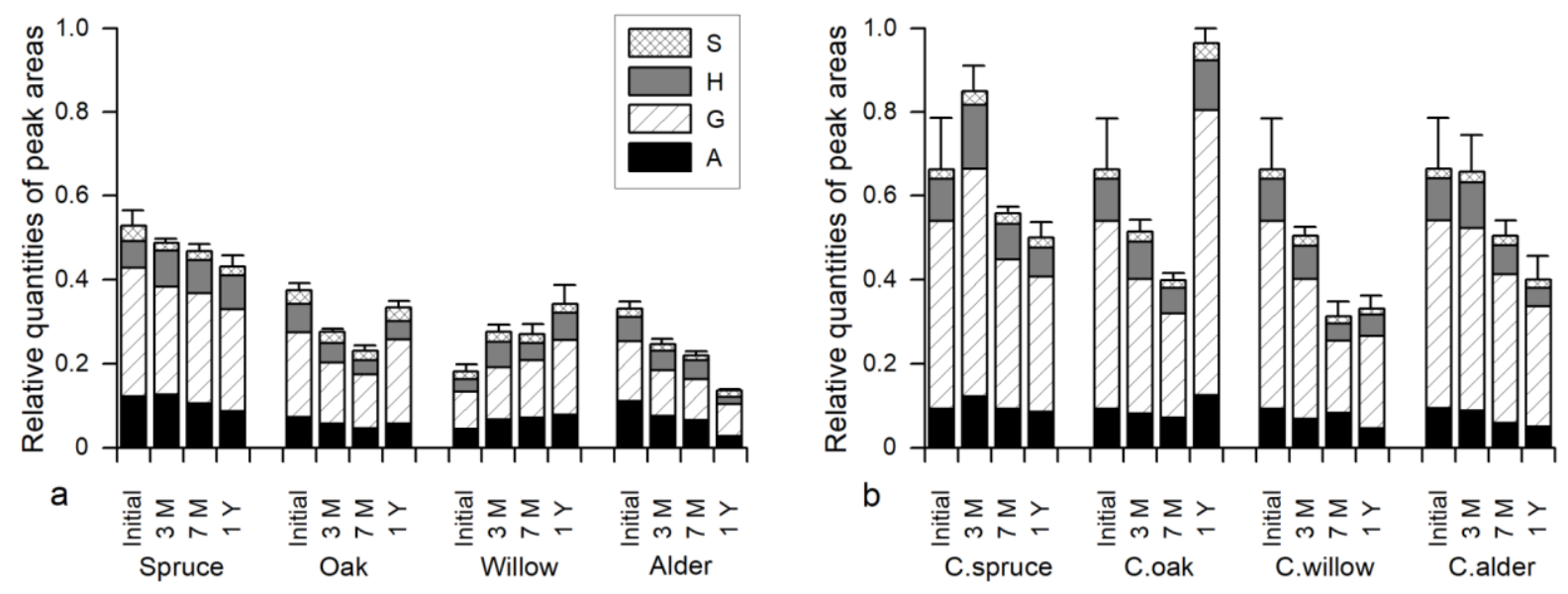

Fig. 2 Lignin composition of (a) spruce, oak, willow, alder, and (b) Calamagrostis litter placed at spruce (C.spruce), oak (C.oak), willow (C.willow), and alder (C.alder) sites for one year. Relative quantities of syringyl (S), hydroxyphenyl $(\mathrm{H})$, guaiacyl $(\mathrm{G})$, and non-assigned aromatic (A) units are shown. The data represent means and SEM and are based on peak areas divided by mass of the sample based on TMAH-Py-GC-MS. 


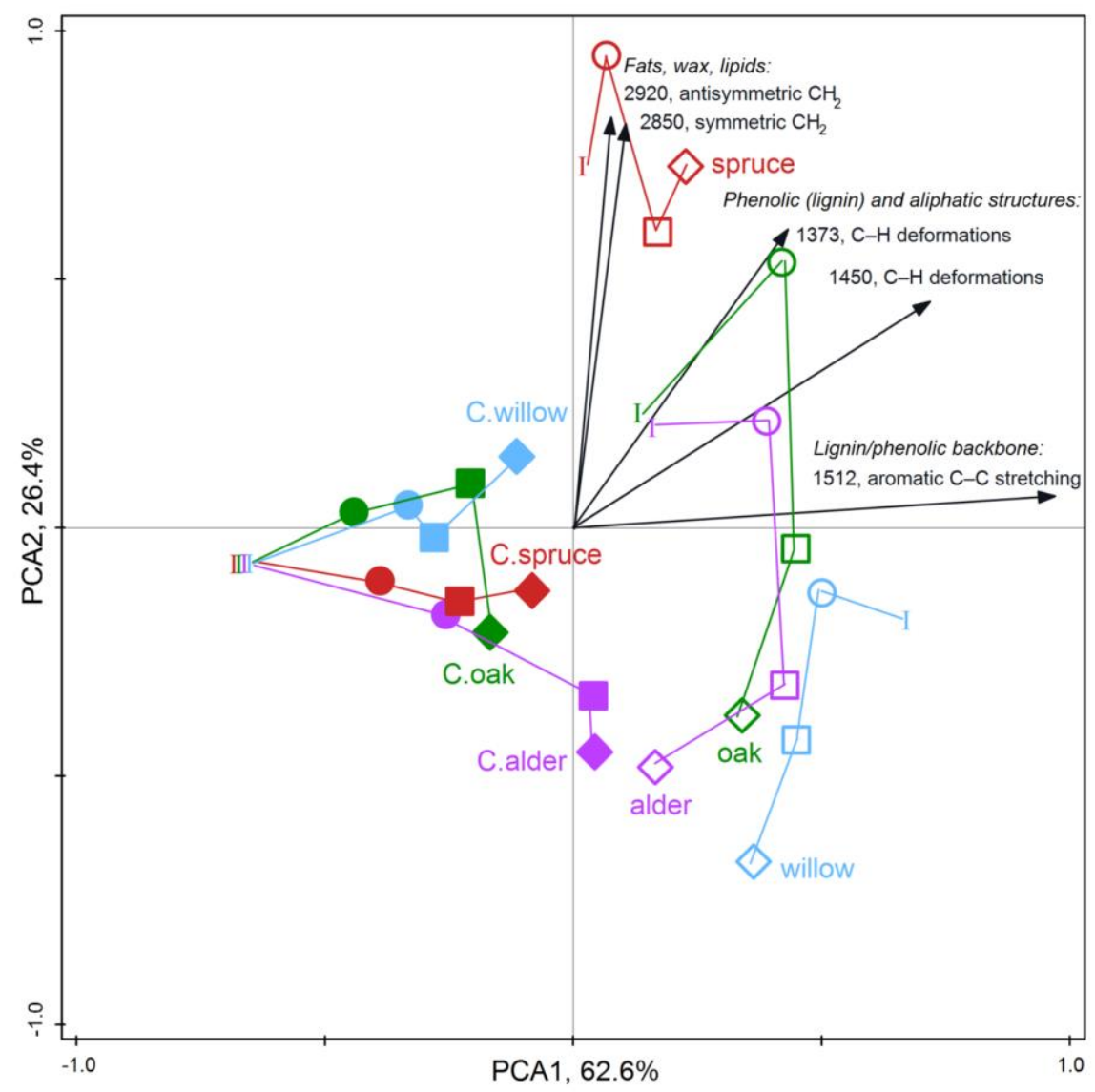

Fig. 3 Principal component analysis (PCA) ordination diagram based on the FTIR absorbance data between 2966 and $2700 \mathrm{~cm}^{-1}$ and 1800 and $1190 \mathrm{~cm}^{-1}$, showing shifts in litter quality from initial litter (I) to litter after three, seven, and twelve months of decomposition. Arrows indicate intensities of the main absorption bands assigned according to Artz et al. 2008. 

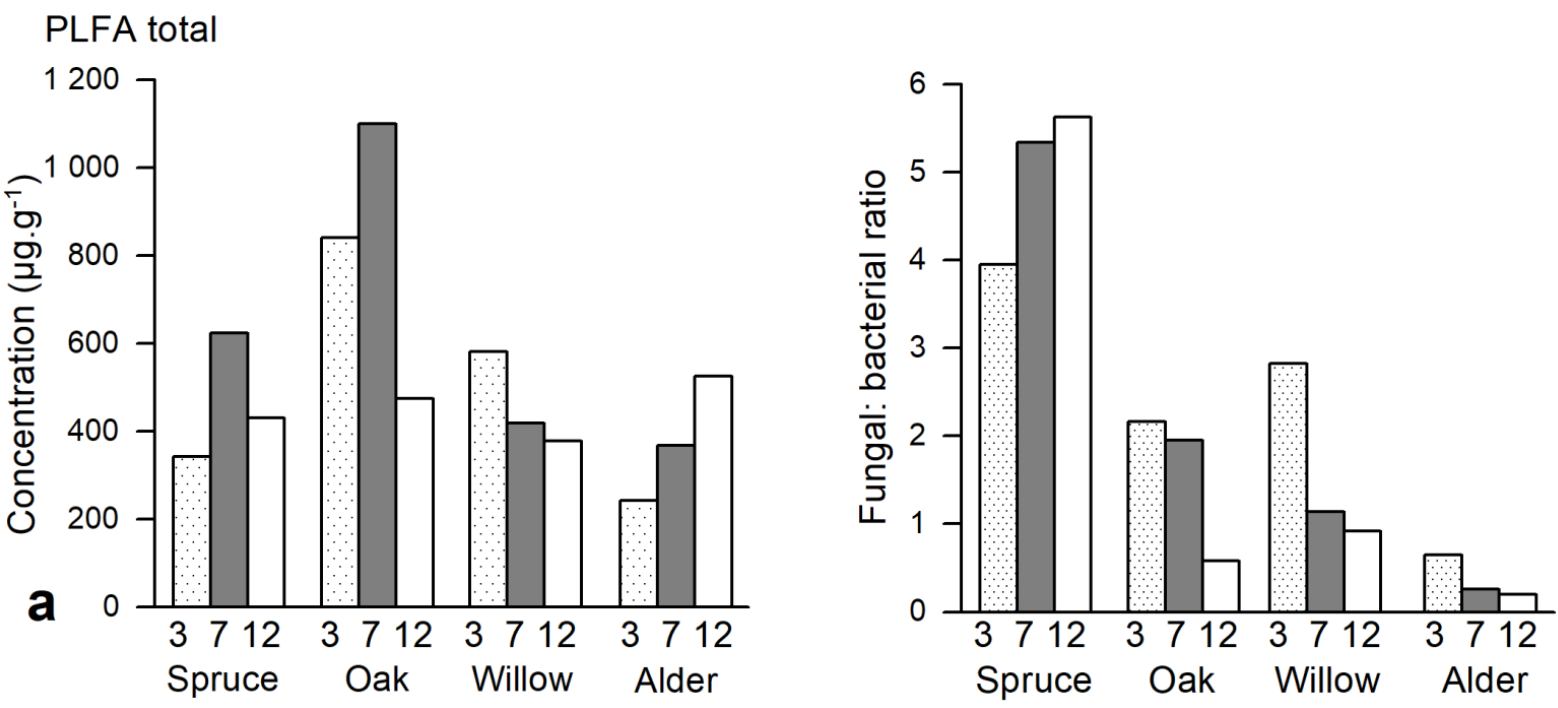

\section{PLFA total}
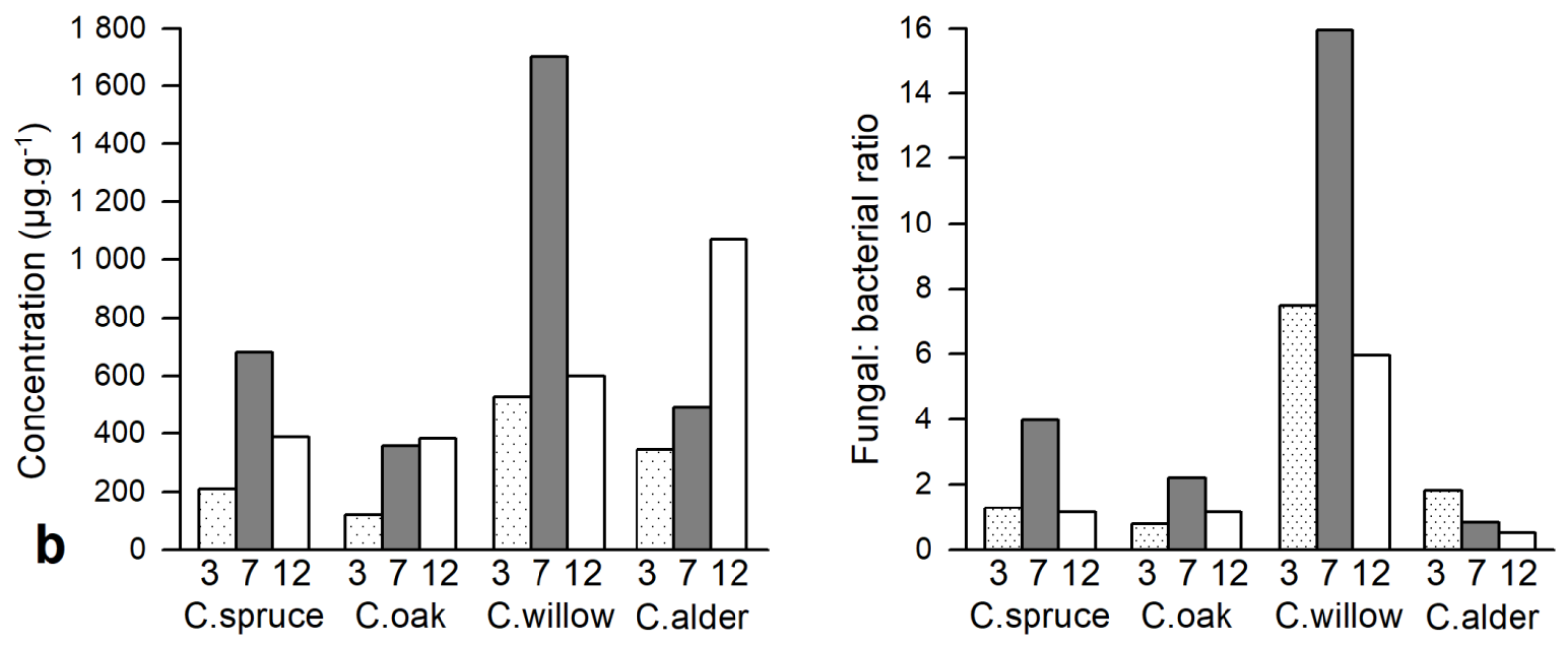

Fig. 4 Course of microbial biomass content in litter of (a) spruce, oak, willow, alder, and (b)

Calamagrostis placed at spruce (C.spruce), oak (C.oak), willow (C.willow), and alder (C.alder) sites during the one-year decomposition experiment. 

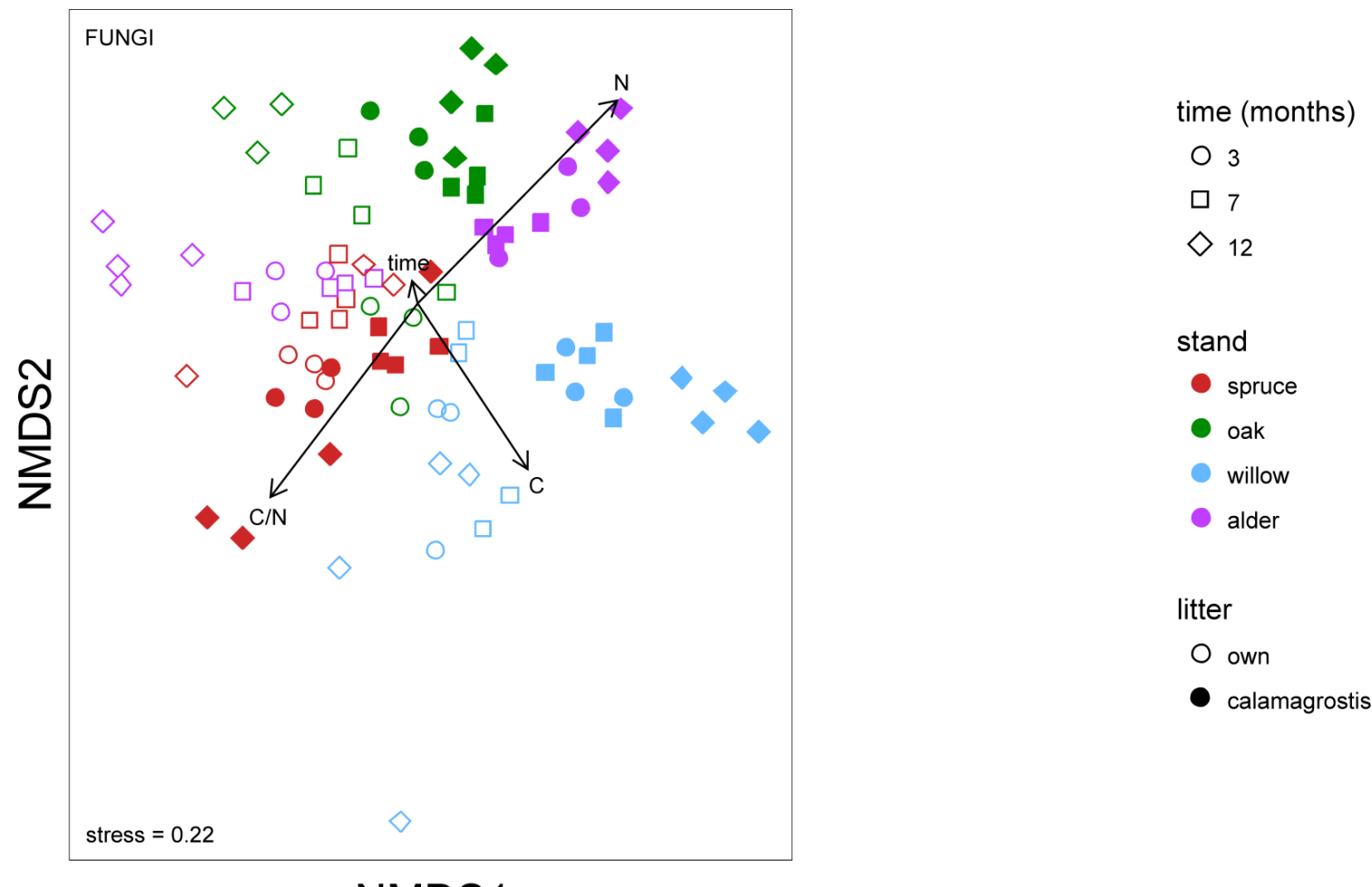

NMDS1

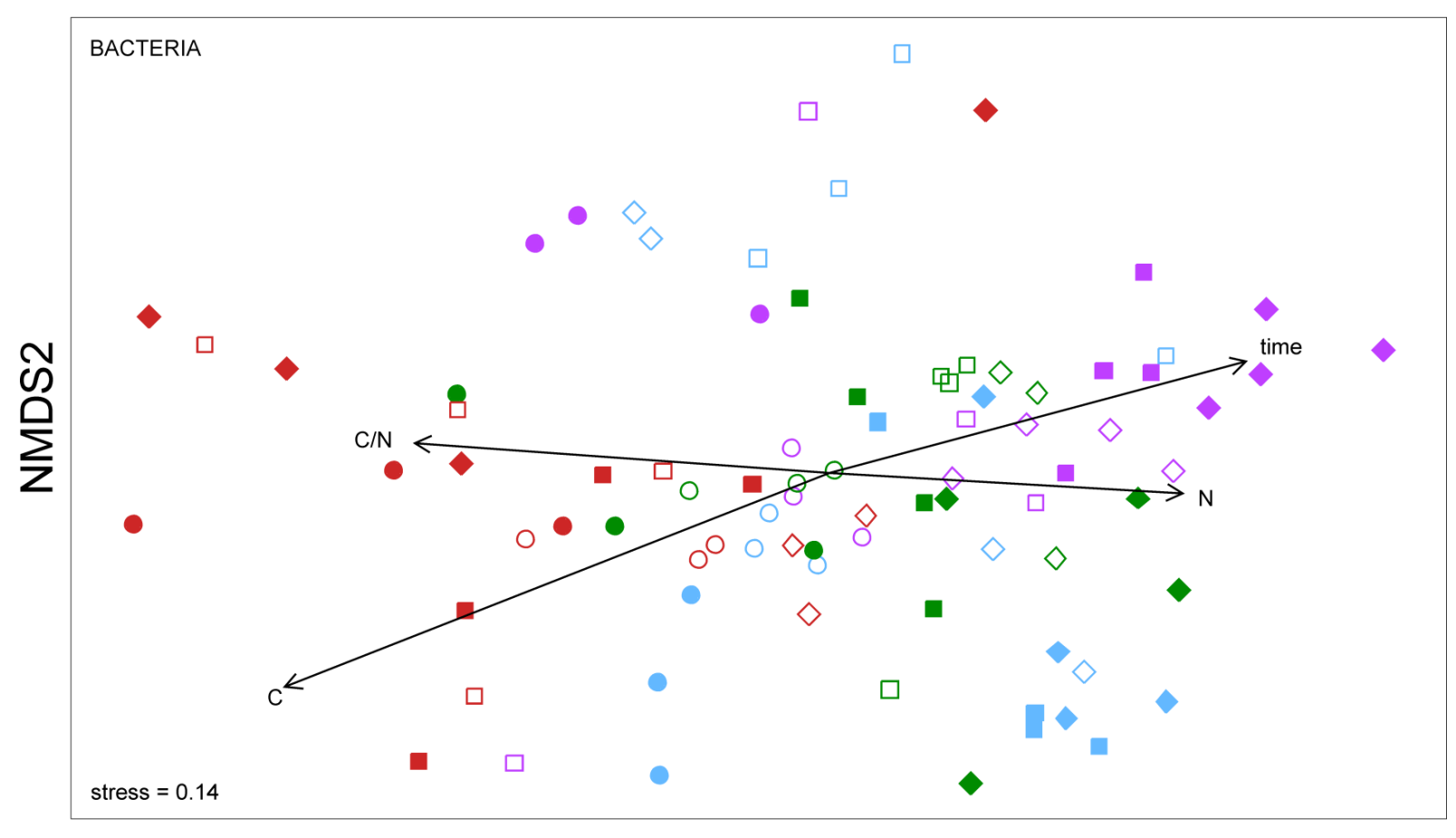

NMDS1

Fig. 5 Microbial communities in decomposing tree (spruce, oak, willow, alder) and Calamagrostis litter. Non-metric multidimensional scaling (NMDS) ordination calculated on OTU abundances. Vectors representing environmental variables significant according to the permutation test $(\mathrm{P}<0.05)$ are included. 


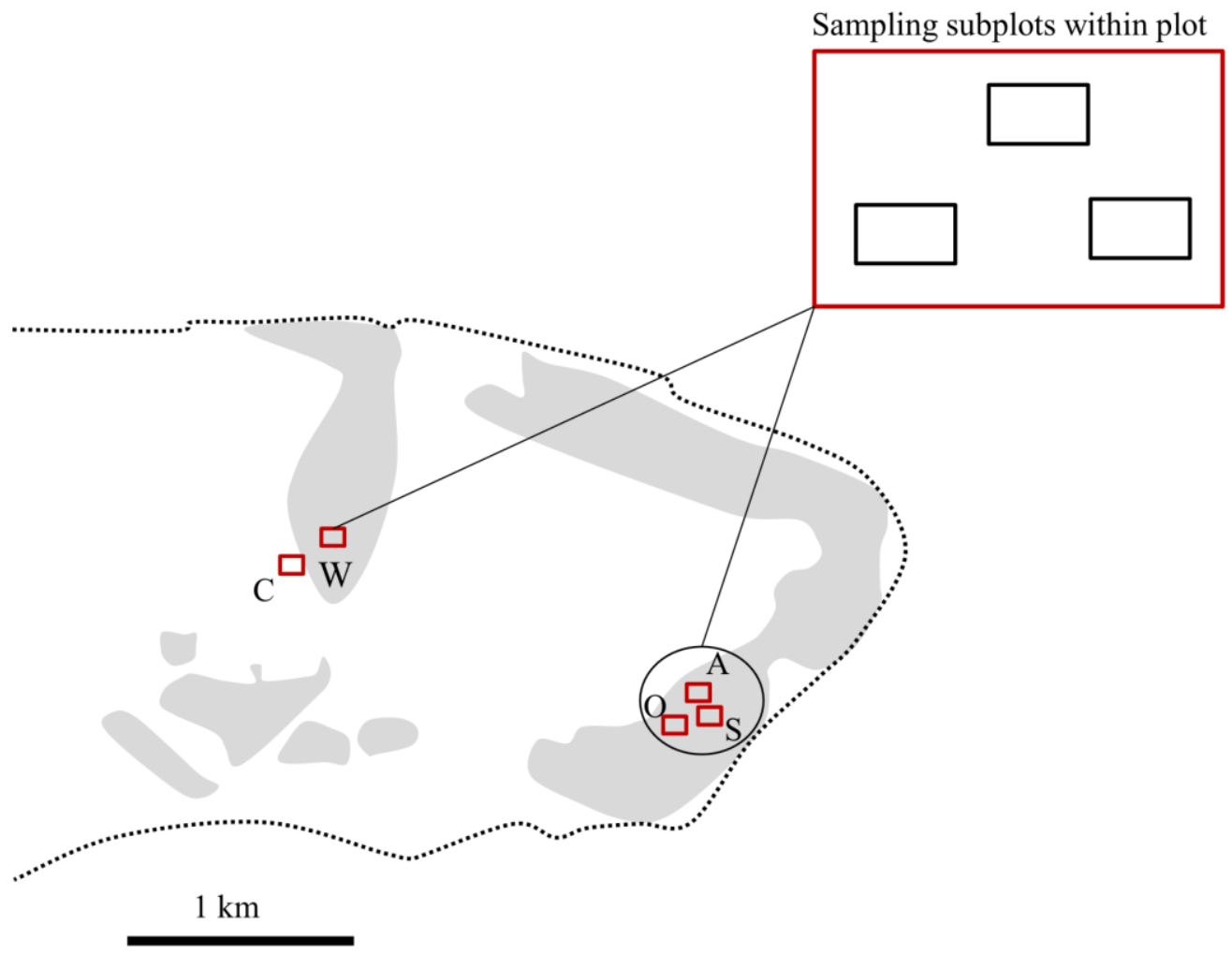

Suppl. Fig. S1 Sketch of individual study sites in the post-mining area. The area is marked by a dashed line. Shaded parts mark areas covered by woody vegetation. Plots chosen for litter sampling (S, O, W, A, C) and placing of litterbags (S, O, W, A) are marked by red squares: S - spruce, $\mathrm{O}$ - oak, W - willow, A - alder, C - Calamagrostis. The sketch is modified from a study of Frouz et al. (2013). 

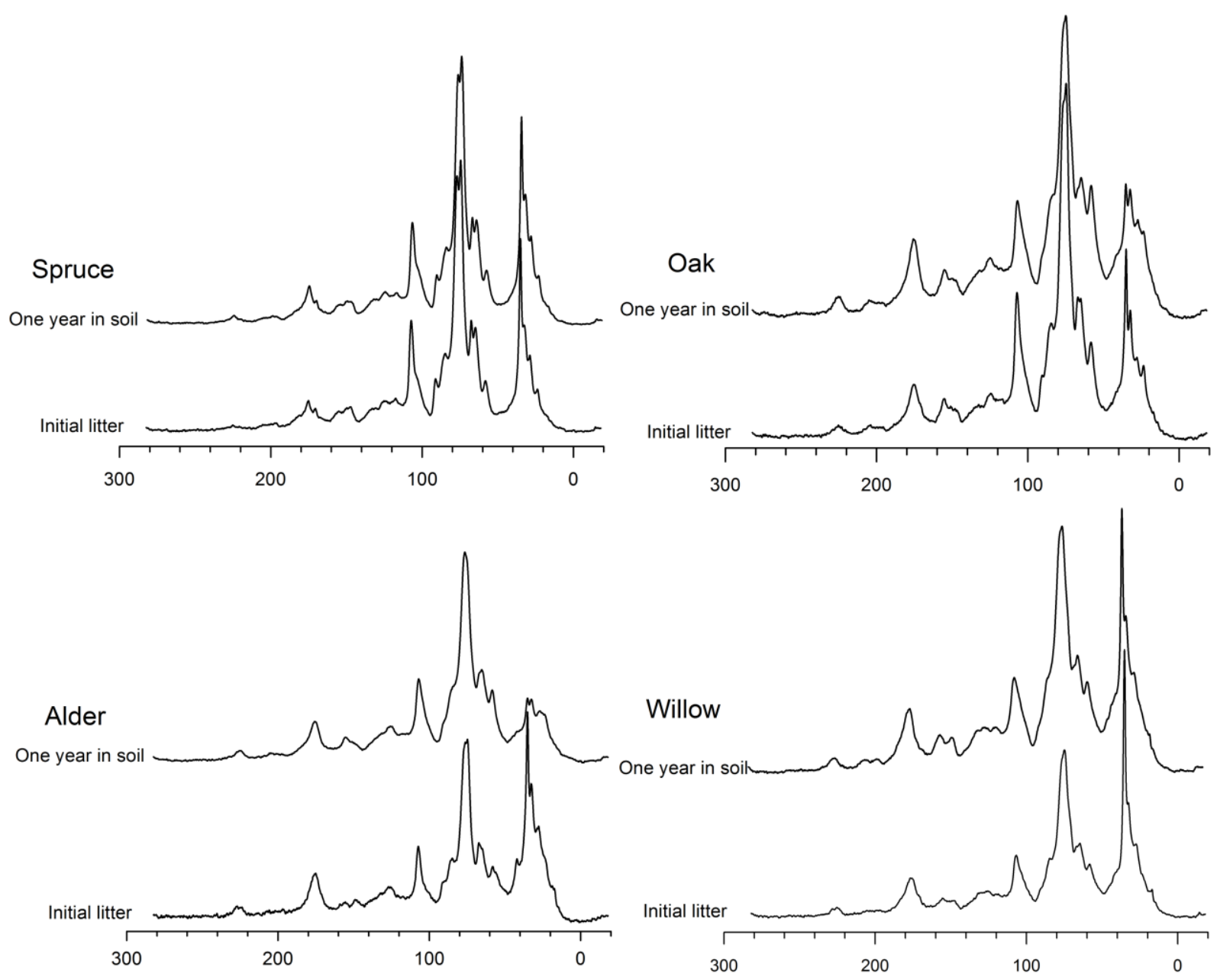

Suppl. Fig. S2 Solid-state ${ }^{13}$ C NMR spectra of initial leaf litter of dominant trees (spruce, oak, alder, willow) and litter after one year of decomposition. 


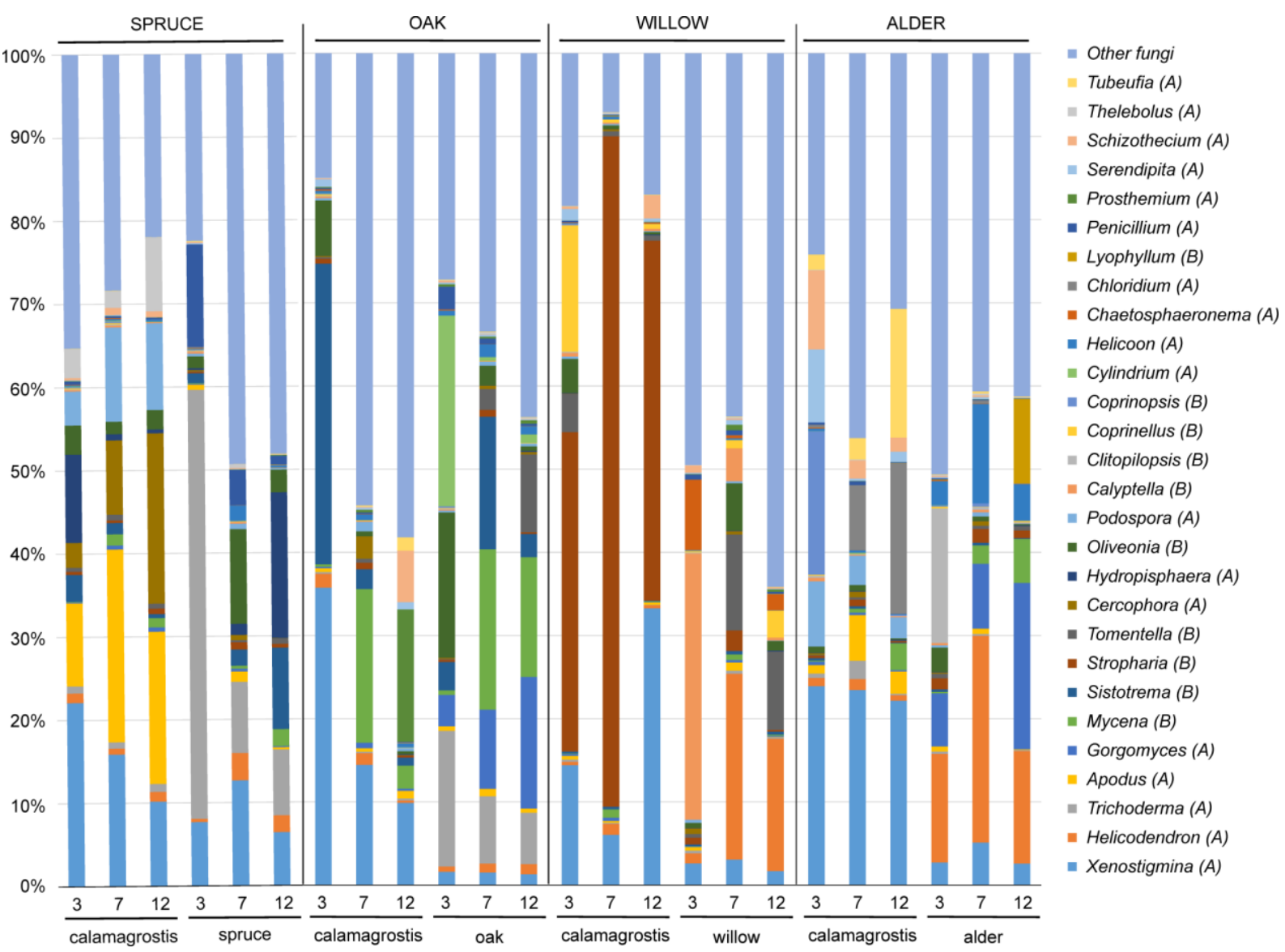

Suppl. Fig. S3 Composition of fungal communities in tree (spruce, oak, willow, alder) and Calamagrostis litter. The data represent means of four replicates and are based on sequence abundances. 


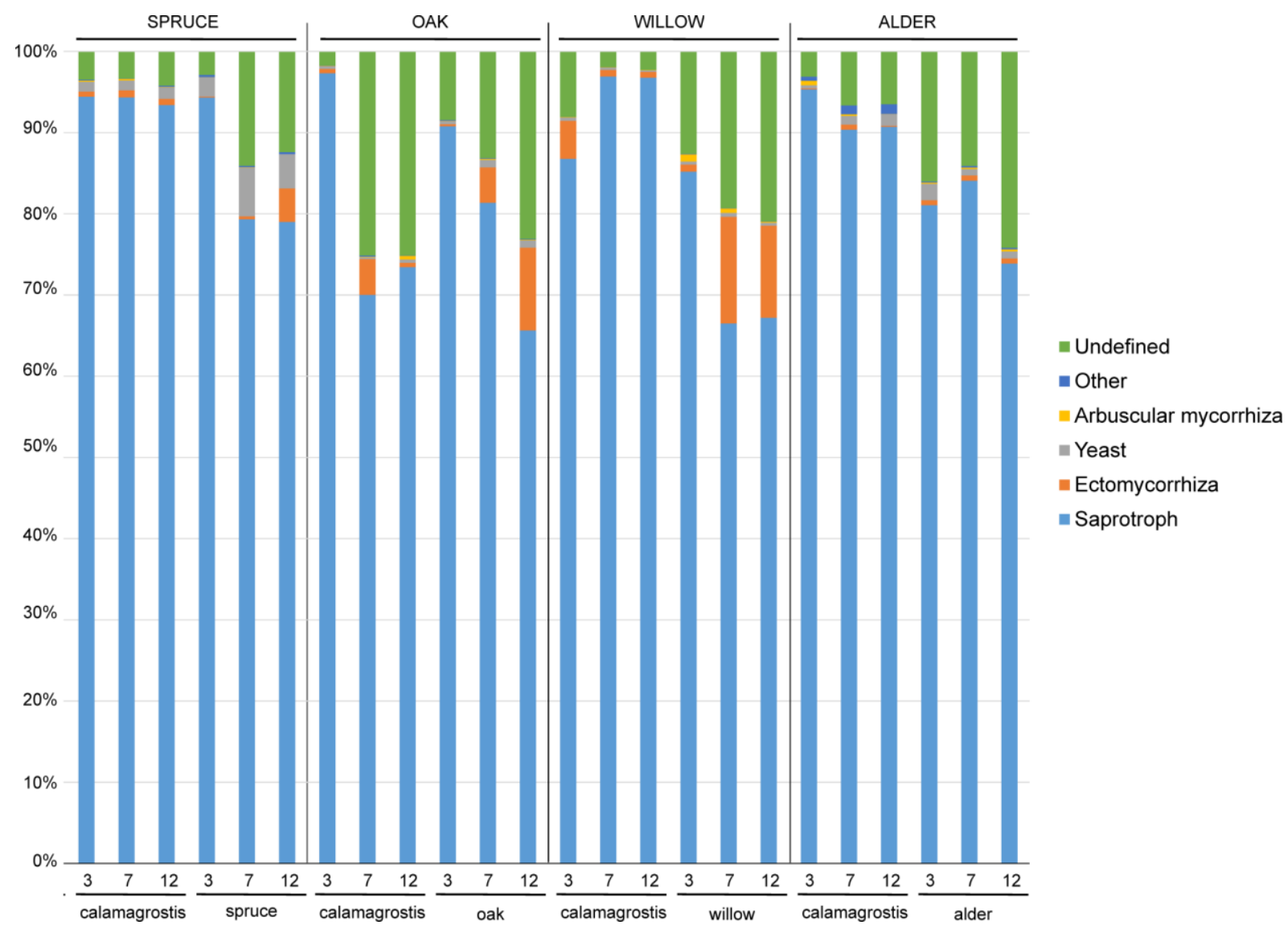

Suppl. Fig. S4 Functional groups of fungi in tree and Calamagrostis litter. The data represent means of four replicates and are based on sequence abundances. 


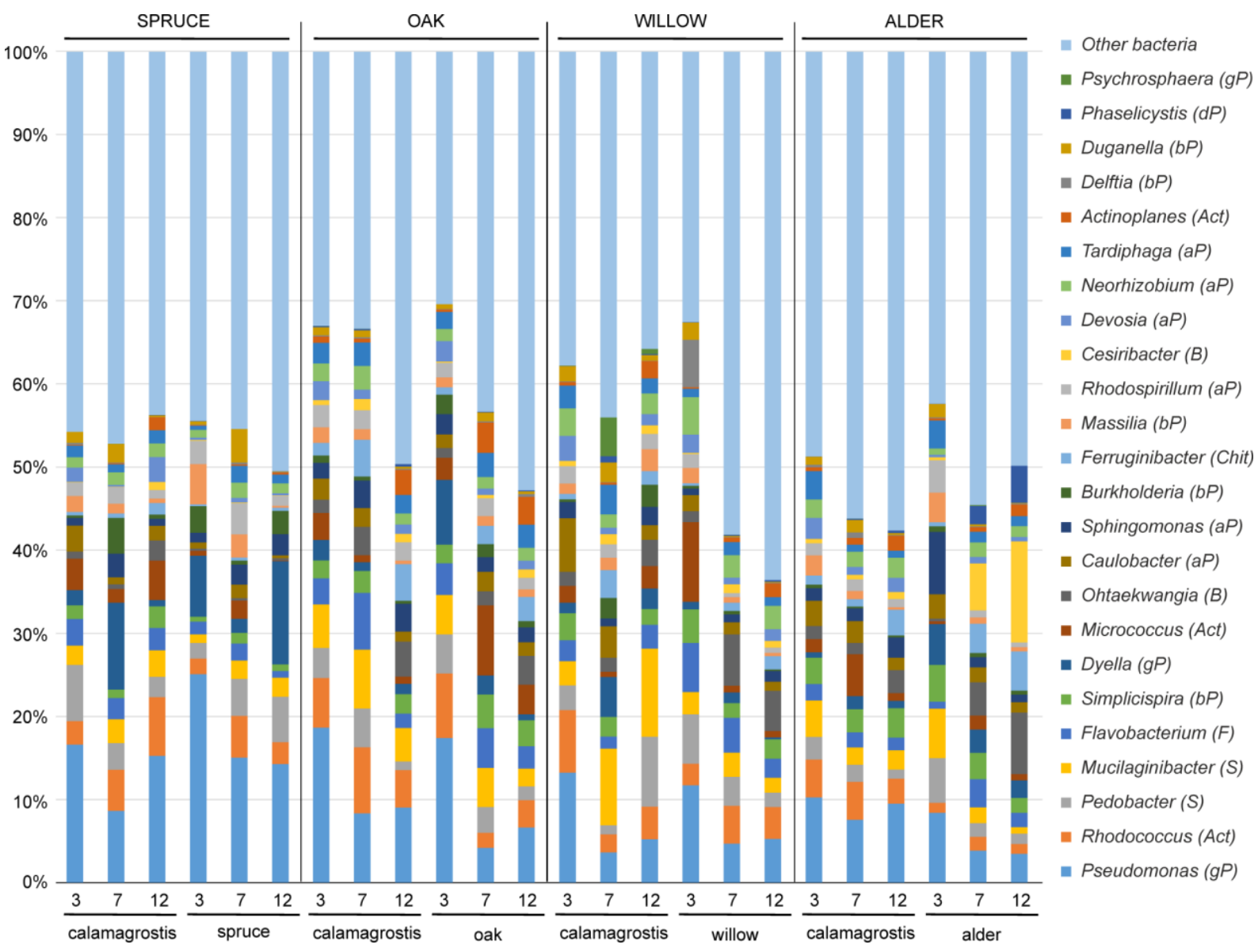

Suppl. Fig. S5 Composition of bacterial communities in tree (spruce, oak, willow, alder) and Calamagrostis litter. The data represent means of four replicates and are based on sequence abundances. 